INTER NATIONAL MONETARY FUND
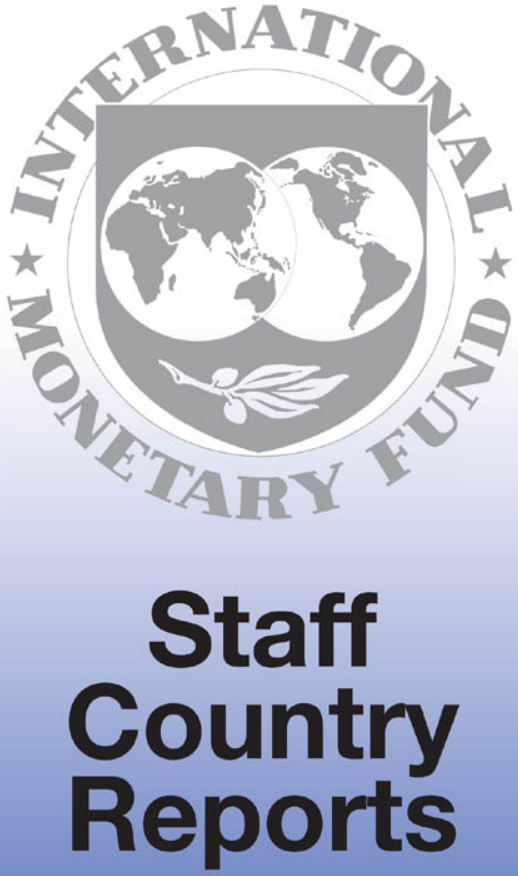


\section{Republic of Tajikistan: Fifth Review Under the Three-Year Arrangement Under the Extended Credit Facility, Request for Waiver of Nonobservance of Performance Criteria, and Request for Modification of Performance Criteria-Staff Report; Press Release on the Executive Board Discussion; and Statement by the Executive Director for the Republic of Tajikistan.}

In the context of the fifth review under the three-year arrangement under the extended credit facility, request for waiver of nonobservance of performance criteria, and request for modification of performance criteria, the following documents have been released and are included in this package:

- $\quad$ The staff report for the fifth review under the three-year arrangement under the Extended Credit Facility, request for waiver of nonobservance of performance criteria, and request for modification of performance criteria, prepared by a staff team of the IMF, following discussions that ended on September 21, 2011, with the officials of Tajikistan on economic developments and policies. Based on information available at the time of these discussions, the staff report was completed on December 22, 2011. The views expressed in the staff report are those of the staff team and do not necessarily reflect the views of the Executive Board of the IMF.

- $\quad$ A Press Release summarizing the views of the Executive Board as expressed during its January 9, 2012 discussion of the staff report that completed the request and/or review.

- A statement by the Executive Director for Tajikistan.

The documents listed below have been or will be separately released.

Letter of Intent sent to the IMF by the authorities of Tajikistan*

Memorandum of Economic and Financial Policies by the authorities of Tajikistan*

Technical Memorandum of Understanding*

Poverty Reduction Strategy Paper

*Also included in Staff Report

The policy of publication of staff reports and other documents allows for the deletion of market-sensitive information.

Copies of this report are available to the public from

International Monetary Fund • Publication Services

$70019^{\text {th }}$ Street, N.W. • Washington, D.C. 20431

Telephone: (202) 623-7430 • Telefax: (202) 623-7201

E-mail: publications@imf.org Internet: http://www.imf.org

\section{International Monetary Fund Washington, D.C.}


This page intentionally left blank

CInternational Monetary Fund. Not for Redistribution 
INTERNATIONAL MONETARY FUND

REPUBLIC OF TAJIKISTAN

\title{
Fifth Review Under the Three-Year Arrangement Under the Extended Credit Facility, Request for Waiver of Nonobservance of Performance Criteria, and Request for Modification of Performance Criteria
}

\author{
Prepared by the Middle East and Central Asia Department \\ in Consultation with Other Departments \\ Approved by David Owen and Dhaneshwar Ghura
}

December 22, 2011

Mission: Discussions were held in Dushanbe during September 12-21, 2011 for the fifth review under the three-year arrangement under the Extended Credit Facility (ECF).

Team: Messrs. Schneider (head) and Junius, Memes. Unigovskaya and Cerovic (all MCD), and Ms. Bal Gunduz (SPR). Mr. Aisen, the resident representative, assisted the mission.

Key Tajik officials: President Rahmon, Head of President's Office Davlatov, Minister of Finance Nadjmuddinov, National Bank of Tajikistan (NBT) Chairman Rahimzoda, and Minister of Economic Development and Trade Hamraliev.

Fund relations: A three-year, US\$116 million (90 percent of quota) arrangement under the ECF was approved by the IMF's Executive Board on April 21, 2009, and augmented to US\$152 million (120 percent of quota) on June 7, 2010 (EBS/10/95).

Exchange system: Tajikistan has accepted the obligations under Article VIII, Sections 2,3 , and 4 , and maintains an exchange system free of restrictions on payments and transfers for current international transactions. The de facto exchange rate regime has been classified as crawl-like since March 2011.

ECF: The authorities met the program's quantitative performance criteria for end-June with two exceptions. In the Memorandum of Economic and Financial Policies (MEFP) attached to President Rahmon's Letter of Intent (LOI), the authorities outline their economic program covering the period through March 2012, for which they seek support under the ECF.

Data: Despite some weaknesses, data provision is broadly adequate for surveillance. Tajikistan participates in the GDDS.

Outreach: The mission met with local representatives of the donor community, including the Asian Development Bank (ADB), the World Bank, and the European Union, and briefed members of the diplomatic community. The mission also gave a press briefing. 


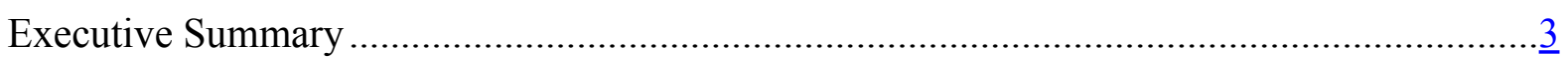

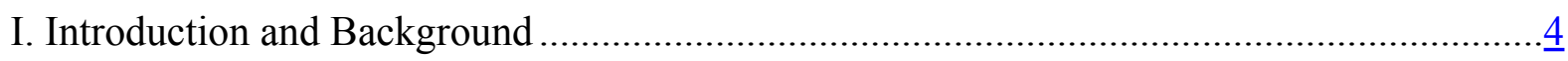

II. Recent Economic Developments and Performance Under the ECF ……............................ 4

A. Key Economic Developments..........................................................................

B. Program Performance..................................................................................

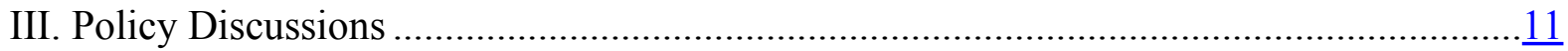

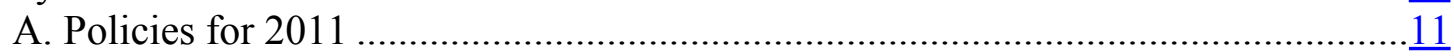

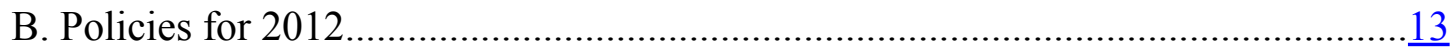

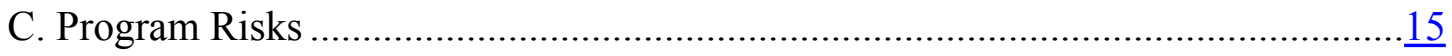

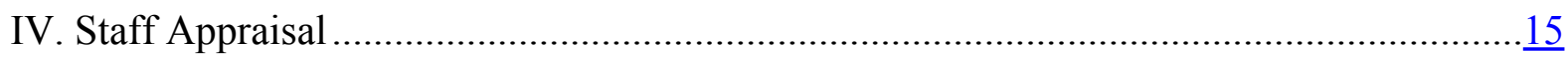

Tables

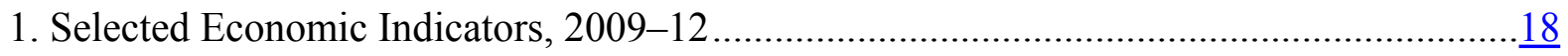

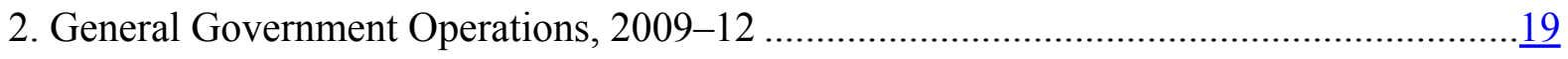

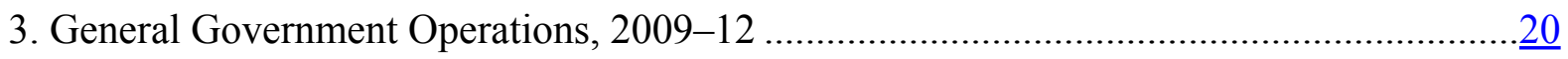

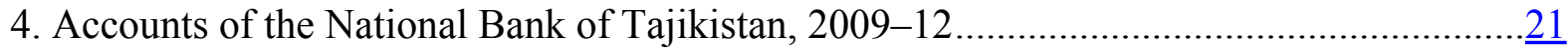

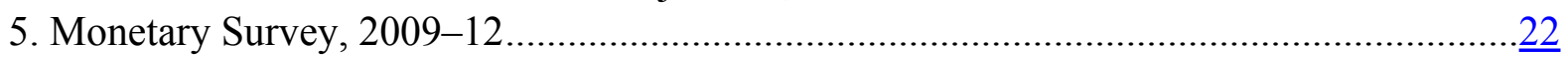

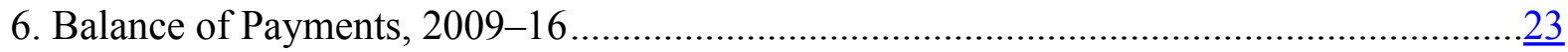

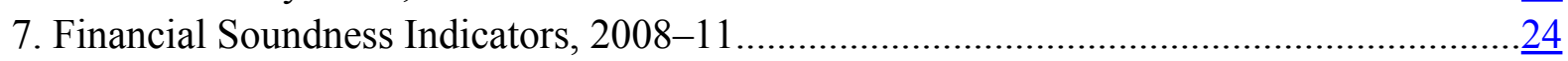

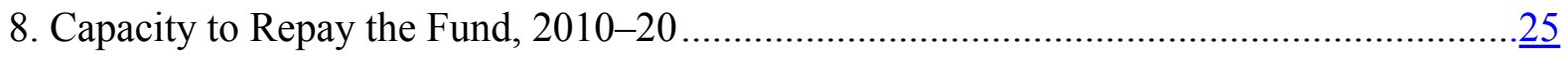

9. Reviews and Disbursements under the Three-Year ECF Arrangement, 2009-12 …........... 26

Box

Global Uncertainties—Downside Risks for Tajikistan.......................................................

Attachments

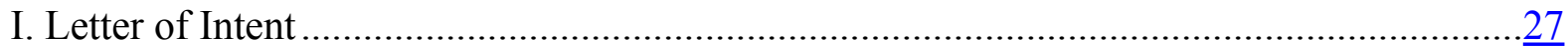

II. Memorandum of Economic and Financial Policies .......................................................

III. Addendum Technical Memorandum of Understanding ............................................... 


\section{EXECUTIVE SUMMARY}

\section{Economic growth in Tajikistan remains strong despite external shocks, but risks}

remain. Below average rainfall in the first part of the year led to early concerns about agriculture, hydroelectricity, and industrial production. However, agricultural output has outpaced expectations, and strong inward remittances have fueled robust growth in trade, services, and construction. Inflation has been high for most of the year. Recent slippages with respect to program objectives signal the need to tighten monetary and expenditure policies and to move quickly on key structural reforms.

\section{The authorities plan to:}

- $\quad$ Tighten monetary policy to bring reserve money growth back in line with program objectives, and alleviate pressures on inflation and the balance of payments.

- $\quad$ Tighten fiscal policy through a more ambitious budget deficit target than originally envisioned-effectively saving revenues from over-performance on tax collection.

- $\quad$ Undertake key structural reforms to improve liquidity management and address structural weaknesses in the financial sector.

- $\quad$ Press ahead with new structural measures to improve public financial management and the tax regime.

\section{Staff agrees with the authorities' policy strategy and notes:}

- The authorities need to enhance coordination of macroeconomic management, and in particular pay careful heed to the impact of quasi-fiscal operations.

- Caution is needed with respect to the macroeconomic implications associated with construction of the Roghun hydropower project. Roghun spending will need to be undertaken and financed in a way consistent with program objectives, macroeconomic stability, and fiscal/debt sustainability.

- $\quad$ Financial sector weaknesses undermine the credibility of local banks, limiting the role that financial intermediation can play in supporting higher and sustained growth. Reform of oversight and supervision, and an end to directed lending are essential.

- $\quad$ Despite favorable growth performance, risks remain on the downside. Fiscal, monetary, and exchange rate policies will need to be responsive to global and regional economic developments. 


\section{INTRODUCTION AND BACKGROUND}

1. Economic activity in Tajikistan continues to recover from the global crisis, but a range of vulnerabilities remain. Real GDP grew at an estimated 7.5 percent through the first nine months of 2011. Rising inward remittances have been key-fueling domestic trade and services. However, agriculture has done surprisingly well despite below average precipitation in the first part of the year, and construction has also grown robustly. Inflation has been a concern, rising in tandem with world food and fuel prices and with the increase in Russian export taxes on refined fuel products starting in May 2011. Headline inflation peaked at nearly 15 percent in May 2011, but declined to 12 percent by September 2011. Core inflation rose quickly after the rise in imported fuel prices, but has since stabilized.

2. Program performance has been mixed. Two quantitative performance targets were missed, reflecting a mixture of external shocks (principally the higher Russian fuel taxes), policy slippage, and underlying structural weaknesses in public financial management and the financial sector. However, all but one of the structural benchmarks for the fifth review have been completed, albeit with some delays. The authorities have agreed on a set of corrective actions to address mid-year slippages, but risks to the program remain high.

\section{The political environment appears broadly stable, but there are underlying} tensions. The worst of the food and fuel price shocks has been weathered without civil unrest, due partly to measures to ensure supplies (even at higher prices), higher remittances, and a general understanding by the population that remedies are limited given resource constraints. The government is seeking to counter religious extremism. Most recently, the government passed the Parental Responsibility Law, which requires youths under the age of 18 to study in secular schools rather than mosques, churches or other religious schools. The prospect of a U.S. drawdown in Afghanistan also raises concerns.

4. The current ECF arrangement expires in April 2012. Given the program's role in maintaining macroeconomic stability, building capacity, and facilitating donor financing and technical assistance, the authorities have expressed interest in continued program engagement.

\section{Recent Economic Developments And Performance Under the ECF}

\section{A. Key Economic Developments}

\section{Economic growth has overcome negative shocks, but inflation has been} persistently high. Low precipitation early in the year raised concerns about the outlook for industrial production (which rests heavily on hydroelectricity supply) and agricultural output. Replanting and a second set of harvests have helped agriculture to recover, however, and have alleviated some concerns about food security. Industrial activity has been slow, reflecting low hydroelectricity production, but construction and domestic trade and services have helped to compensate. Barring new shocks, the 6 percent growth projection under the 
program may prove conservative, but would leave a buffer for adverse developments.

Inflation has been a persistent challenge. Headline CPI peaked at 14.8 percent in May 2011 on the back of higher food and fuel prices, but has since declined as international prices have stabilized. Core inflation was low (about 3 percent on average during January-April 2011) but accelerated following the increase in fuel import prices to over 7 percent by August 2011, reflecting the spillover into services.
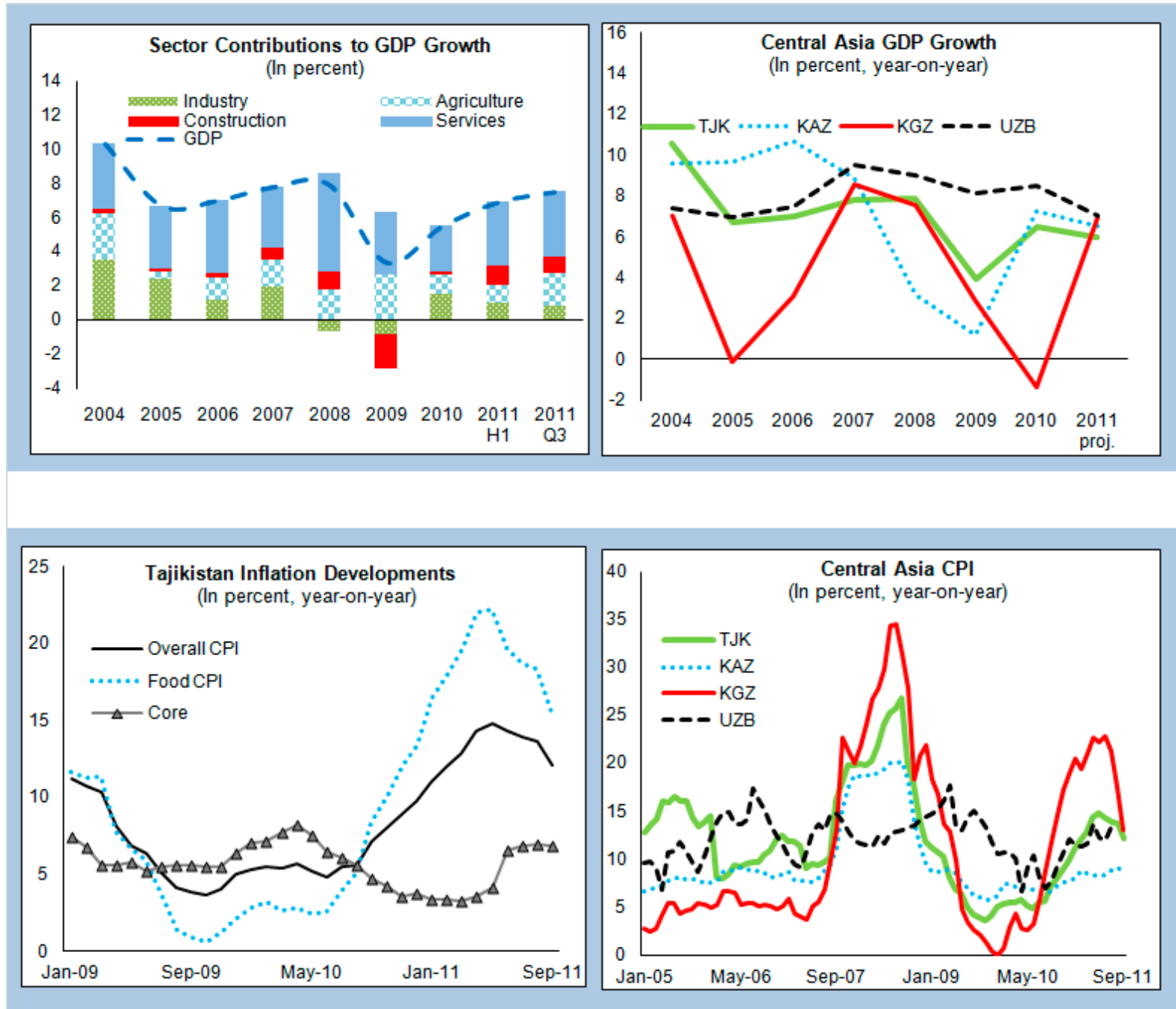

\section{The fiscal accounts over-performed relative to expectations for the first half of}

the year, due largely to higher revenue. While spending was in line with expectations (albeit skewed toward capital expenditure), higher commodity prices led to a substantial increase in collections of VAT on imports and on trade taxes. Overall tax revenue was some 0.4 percent of GDP higher than targeted, and budget support grants some 0.3 percent above projections. As a result, the overall fiscal balance (excluding the externally financed public investment program, PIP) for January-June 2011 registered a surplus of 0.5 percent of GDP, compared with a projected 0.2 percent deficit. 


\section{Accommodative monetary policies and quasi fiscal operations led to a surge in}

reserve money. Reserve money growth - which began the year at over 40 percent due to a surge in NBT liquidity support to banks (related to imports of food and fuel products) declined steadily through March 2011 as much of this credit was unwound. After March, however, and despite a significant increase in the lending rate, liquidity support from the NBT rose again, accelerating reserve money growth. Compounding this problem was a substantial transfer of funds raised during the Roghun financing campaign out of the NBT. ${ }^{1}$ Some of these monies were spent to finance construction activities on the Roghun project, while the rest was transferred to commercial banks. Despite the rise in reserve money growth (37 percent year-on-year growth by June 2011) and in core inflation, monetary policies remained passive. Policy rates and reserve requirements remained steady from March onwards, and market operations (NBT bills) remained minimal.

Tajikistan: Flow of funds of proceeds from Roghun equity campaign and contributions as reported by the MOF (Outstanding stocks in thousands of SM)/1

\begin{tabular}{|c|c|c|c|c|c|c|c|c|c|c|}
\hline & Jan-11 & Feb-11 & Mar-11 & Apr-11 & May-11 & Jun-11 & Jul-11 & Aug-11 & Sep-11 & Oct-11 \\
\hline Treasury Accounts at the NBT 2/ & 343,129 & 375,246 & 358,912 & 277,816 & 289,654 & 240,888 & 205,135 & 111,663 & 111,549 & 164,773 \\
\hline MOF Deposits in Commercial Banks 3/ & 266,501 & 266,501 & 266,501 & 266,474 & 266,535 & 316,667 & 346,698 & 346,727 & 346,726 & 344,728 \\
\hline \multicolumn{11}{|l|}{ Funds from campaign proceeds held by the } \\
\hline MOF and transferred to Roghun OJSC 4/ & 220,626 & 188,509 & 204,843 & 285,939 & 275,252 & 282,379 & 288,511 & 382,251 & 382,251 & 331,119 \\
\hline Total campaign proceeds & 830,256 & 830,256 & 830,256 & 830,229 & 831,441 & 839,934 & 840,345 & 840,642 & 840,526 & 840,621 \\
\hline
\end{tabular}

1/ MOF budgetary funds and Roghun-owned deposits at commercial banks are not included in this table.

2/ Numbers match the NBT reporting excluding interest earned from commercial banks in the amount of SM 19.4 million as of October 2011.

3/ Reported amounts of MOF deposits at commercial banks match figures in the commercial banks balance sheet.

4/ Movements of these flows are temporary budget borrowing from campaign proceeds due to liquidty shortages.

\footnotetext{
${ }^{1}$ Funds raised through sale of shares in the Roghun hydropower project were deposited in the NBT and in commercial banks, and are ascribed to the Roghun Open Joint Stock Company (OJSC) rather than the central government. As such, use of these funds affects neither the government budget balance, nor the program target on the fiscal deficit, but can affect the growth of net domestic assets and reserve money.
} 
8. The external accounts came under stress in April-July 2011, leading to pressure on the somoni and a loss of central bank foreign exchange reserves. While the impact of higher global food and fuel prices was largely anticipated, the sharp increase in Russian export taxes on refined fuels was not. The increase in duties adds an estimated $\$ 44$ million to Tajikistan's import bill for 2011 as a whole. ${ }^{2}$ The sharp rise in these taxes prompted a temporary shut-down of about 80 percent of fuel stations in Dushanbe and a mini-crisis in the foreign exchange market. The NBT allowed the somoni to depreciate - dropping some 2.3 percent vis-à-vis the U.S. dollar during January-April 2011 and another 4.7 percent during May-July_but also intervened by $\$ 35$ million during the peak of the crisis to stabilize the market. The quasifiscal operations with respect to Roghun funds noted above, as well as fiscal and quasi-fiscal spending on Tajikistan's $20^{\text {th }}$ anniversary of independence also likely

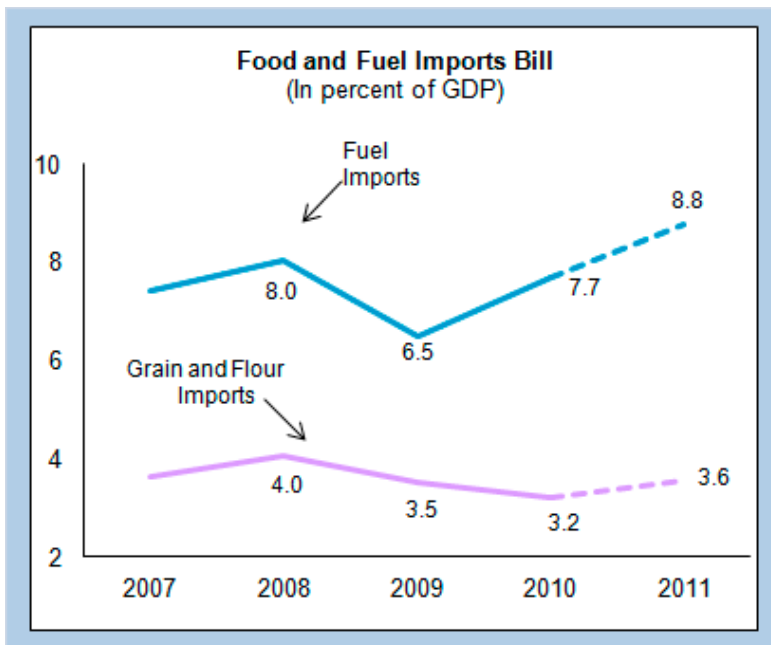
contributed to BOP pressures given heavy import content.

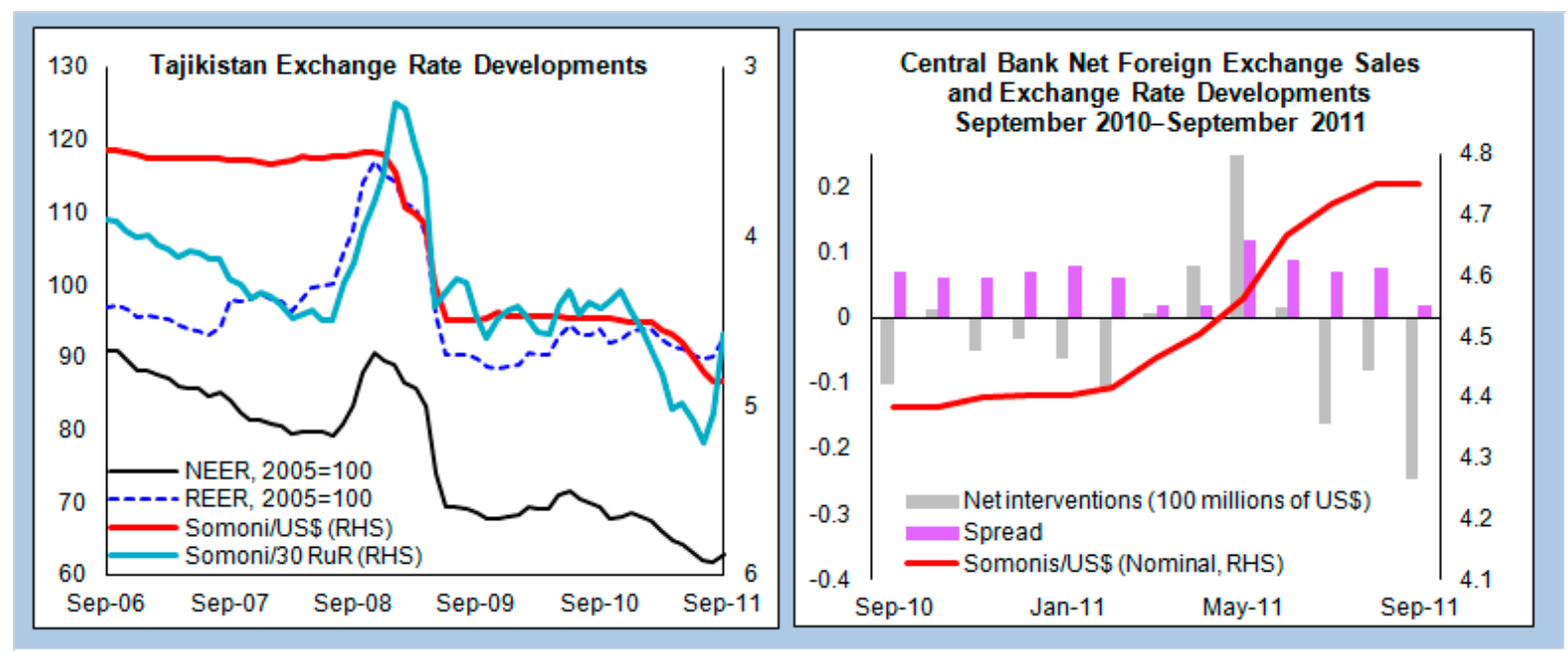

\footnotetext{
${ }^{2}$ Compared to end-2010, export duties imposed by Russia increased by 88 percent for gasoline (58 percent of fuel imports) and 40 percent for other petroleum products. These duties were lowered slightly in subsequent months, but in October gasoline and other products were still 71 percent and 25 percent higher than end-2010 levels, respectively.
} 


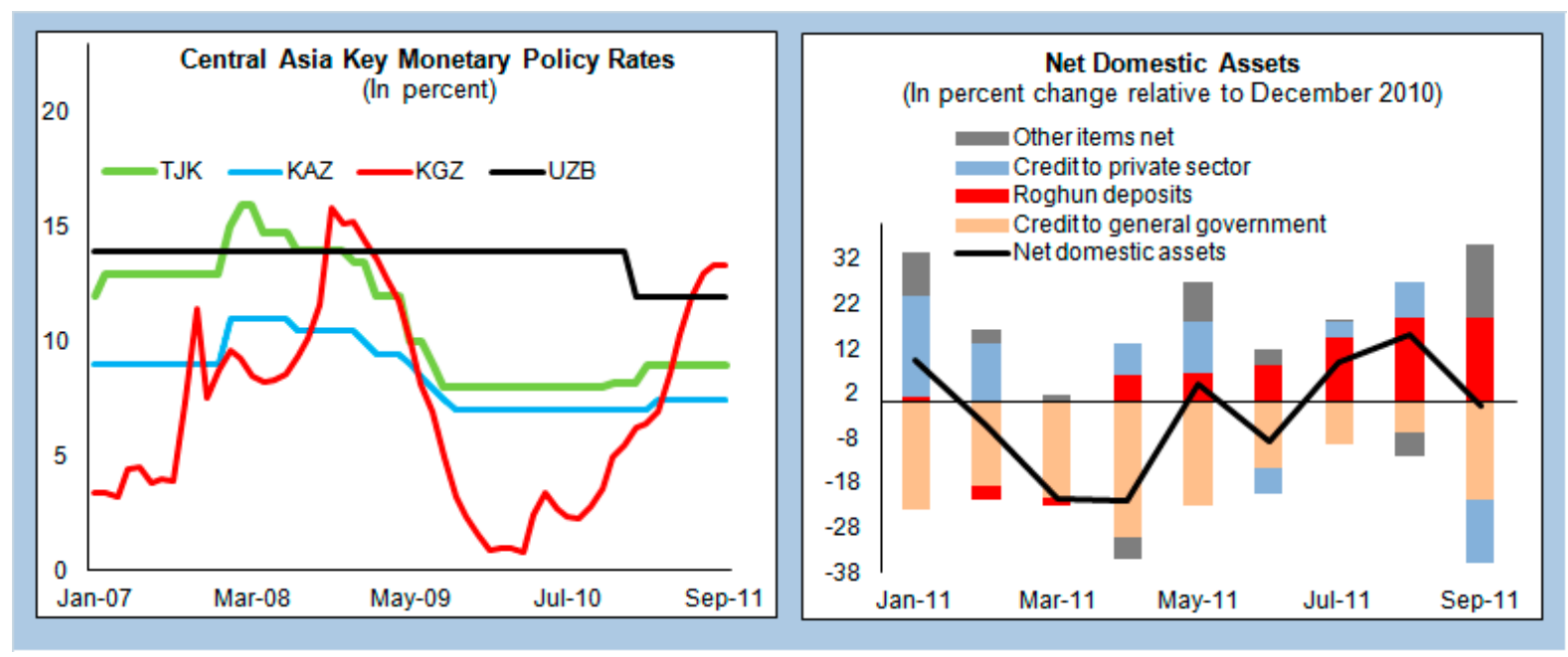

\section{Financial sector indicators have broadly stabilized, but remain weak.}

Nonperforming loans ${ }^{3}$ have fallen from a peak of 28 percent of gross loans in March 2010 to an average of about 17 percent in the first three quarters of 2011. Profitability, however, has declined, with the banking system as a whole barely generating positive returns on assets and equity in the third quarter of the year. Despite significant liquidity lending by the NBT and rising private sector credit, underlying liquidity conditions at banks remain tight—reflecting a mix of insufficient funding, basic asset/maturity mismatches, high levels of nonperforming loans, and directed credit. Bank liquidity is likely to remain constrained as the NBT implements the financial sector action plan, which seeks to bring greater discipline and IFRS standards to the classification of and provisioning for nonperforming loans. In some particular cases, recapitalization may be necessary, and discussions are ongoing on an orderly and meaningful restructuring of problem banks.
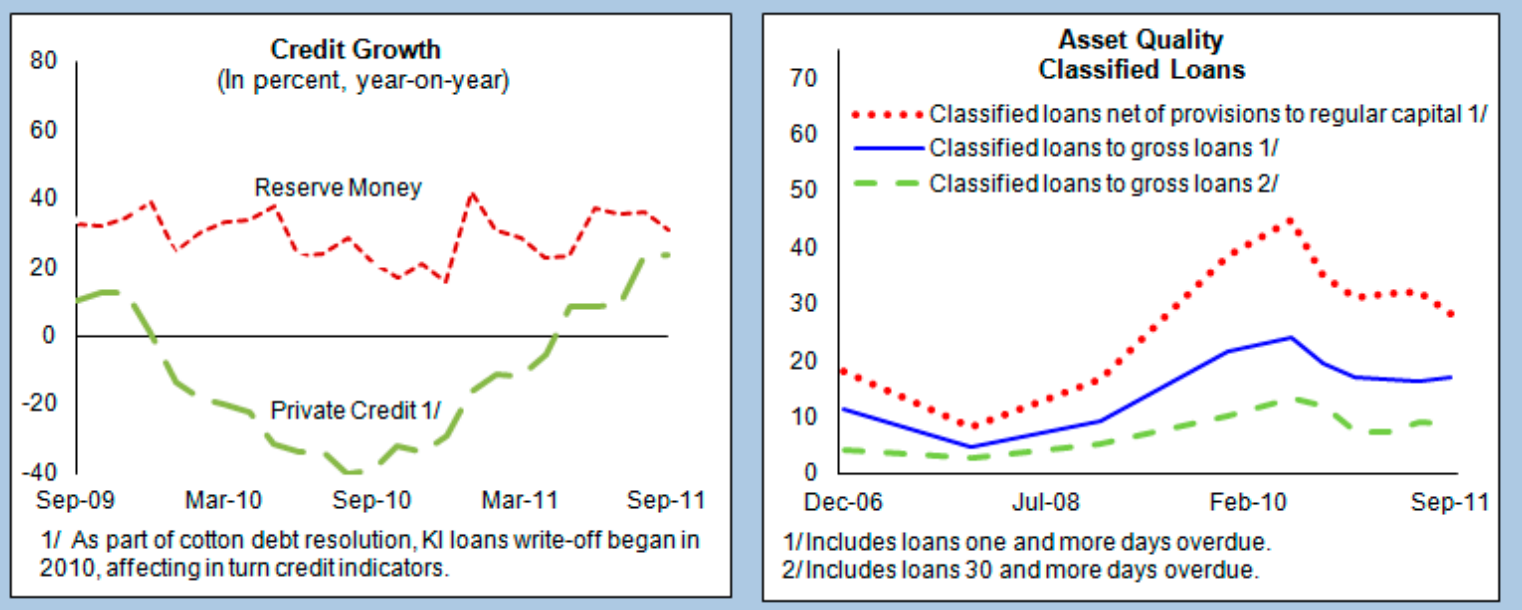

\footnotetext{
${ }^{3}$ Here defined as any loan $1+$ days overdue. Loans $30+$ days overdue are substantially lower.
} 


\section{B. Program Performance}

10. Performance on quantitative targets through end-June 2011 was mixed. Four targets under the program were missed: (i) the performance criterion (floor) on accumulation of net international reserves (NIR) of the NBT; (ii) the indicative target (a quarterly average) on liquidity loans from the NBT to commercial banks; (iii) the indicative target on social spending and (iv) minor accumulations of pension arrears in September and October 2011, which breaches a continuous performance criterion.

- $\quad$ The breach of the NIR target was large - some \$22 million, or about 90 percent of the targeted NIR accumulation for the first half of 2011. The shortfall is largely attributable to the pressures that emerged on the BOP and the exchange rate following the rise in imported fuel prices in May 2011.

- $\quad$ The breach of the indicative target on liquidity loans was not large, but is an endemic problem linked to weaknesses in the financial sector, and continued directed lending. ${ }^{4}$ The scope of the problem is highlighted by the intra-test date levels of liquidity loans, which often rise to more than double the targeted average.

- $\quad$ The shortfall in social spending reflects (i) the timing of social sector public wage increases (which were expected in the first half of the year, but were delayed until September 2011); and (ii) vacancies in social sector civil service positions. ${ }^{5}$

- Pension arrears were minor and cleared in a short period. Pension arrears in the amount of SM 4 million ( 0.01 percent of GDP) were accumulated in September and October 2011, but cleared by October 20 and November 30, 2011, respectively.

\section{The gap vis-à-vis the indicative target for liquidity loans widened after June} 2011, while core inflation continued to rise. Liquidity loans surged to SM 264 million and SM 288 million in July and August 2011, respectively, and to SM 360 million in midSeptember 2011 when the mission was in Dushanbe (compared with a targeted average of SM 180 million for the third quarter under the program). While the official budget continued to over-perform and against the drop in Roghun deposits at the NBT, average year-on-year reserve money growth accelerated to 36 percent during June-August 2011 which the mission saw as problematic given signs of rising core inflation and evident pressure on the balance of payments and the exchange rate.

\footnotetext{
${ }^{4}$ For additional detail on Tajikistan's financial sector, see the Staff Report for the 2011 Article IV Consultation and Fourth Review Under the ECF, EBS11/64.

${ }^{5}$ The budget accounts wages and salaries for a full complement of education and health-care employees, but given ongoing vacancies this target is rarely met—-leading to a tendency for this target to be missed.
} 


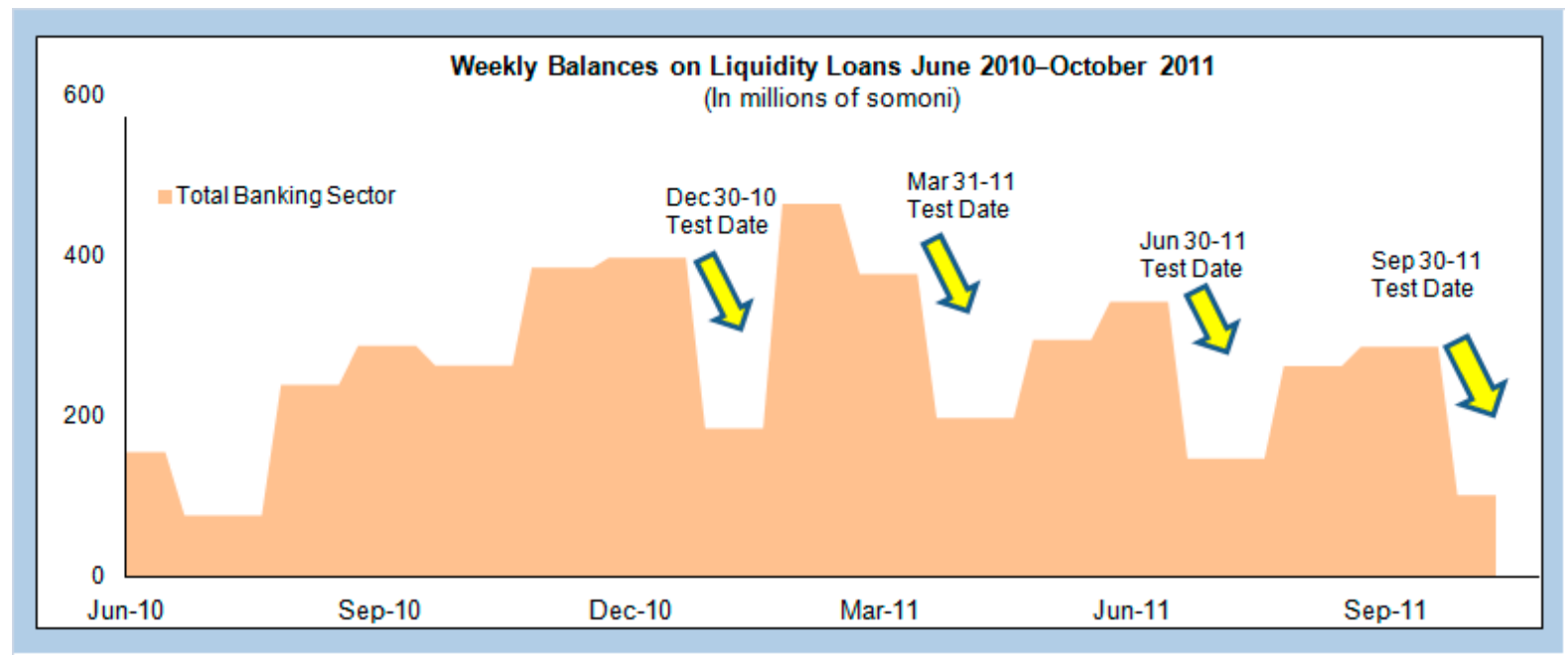

\section{Performance on the structural side has been comparatively strong. The} authorities have completed - albeit with some delays - all but one of the structural benchmarks for June and September 2011. Particularly noteworthy were (i) completion and publication of an external audit on Talco Management; (ii) expanding the coverage of the Large Taxpayer Inspectorate; (iii) passage of a financial sector stability plan, geared at addressing weaknesses in financial sector supervision, accounting, and provisioning; (iv) a government resolution formalizing government recapitalization of the $\mathrm{NBT}^{6}$; and (v) the government's decision to redraft the tax code in line with FAD recommendations. Further, reflecting commitments under the MEFP, a public shareholder's meeting for the Roghun Open Joint Stock Company (OJSC) was held in Dushanbe in May 2011 — the first such meeting in Tajikistan. Roghun OJSC also continues to publish quarterly reports on its operations. Two structural benchmarks were delayed, however:

- $\quad$ One benchmark for June 2011 (the external audit for Roghun OJSC) has been delayed for technical reasons. ${ }^{7}$

- $\quad$ A structural benchmark for September 2011 (publication of the NBT's audited 2010 financial statements) was only completed on December 13, 2011. The findings of the audit entail significant technical revisions. ${ }^{8}$ A full reconciliation of these changes will

\footnotetext{
${ }^{6}$ The first injection of government capital is expected to be completed by end-2011.

${ }^{7}$ A prerequisite to the financial audit is a survey of fixed assets (work completed). To achieve cost savings, the authorities have opted to use a survey of fixed assets being carried out as part of the World Bank's technoeconomic feasibility study, but this survey could not be completed in time to allow for the financial audit by the end-June 2011 deadline. The authorities have asked to re-phase this benchmark to end-March 2012.

${ }^{8}$ The audit proposed some 23 corrections and 11 reclassifications - which the authorities are implementing. The most significant components included (i) removal of non-monetary gold belonging to the MOF from the
}

(continued) 
be presented in a revised NBT balance sheet and monetary survey by the time of the sixth review. In the meantime, data provided by the authorities indicates no adverse impact on program performance from these adjustments, and that no past or current performance criteria have been breached as a result.

\section{Policy Discussions}

In staff's view, slippages in June 2011 and subsequent months involved (i) unexpected shocks-particularly to the balance of payments and the exchange rate; (ii) explicit policy slippage - principally loose monetary policy and quasi-fiscal spending contributing to overly rapid reserve money growth; and (iii) lack of coordination on liquidity management between the MOF and the NBT. Some of the lost ground can be made up, but a full recoup of NIR is unlikely to be feasible by end-December 2011. As such, the staff proposes a combination of (i) revised, achievable PCs in a sustainable macroeconomic framework which include, inter alia, corrective actions to address slippages evident in June 2011 and subsequent months; (ii) prior actions to aid corrective actions and demonstrate policy commitment; and (iii) additional structural benchmarks to shore-up institutional capacity and further mitigate the risk of future policy slippage.

\section{A. Policies for 2011}

\section{The main objective in the last few months of $\mathbf{2 0 1 1}$ has been to adjust for external} shocks and to address the policy slippages that led to the breach of program targets. In this context, the authorities have proposed revisions to the macroeconomic framework and program targets as outlined in Tables 1-6. The key goal has been to bring reserve money growth back to a non-inflationary path and, inter alia, relieve pressure on the BOP and the exchange rate.

14. Revised program targets. The revised targets allow for a shift in the mix of NDA and NIR, while remaining consistent with non-inflationary reserve money growth. The accumulation of NIR for end-December 2011 is lowered from $\$ 70$ million to $\$ 32$ millionrecognizing the impact of the Russian fuel export tax shock, but targeting net accumulation of about \$29 million in the second half of 2011. NDA is adjusted upwards to reflect the transfer of Roghun deposits as well as some adjustment to other items net (OIN).

15. Monetary tightening to regain control of domestic liquidity and reserve money growth is essential to containing upward pressures on core inflation and to stem pressures

balance sheet (to a memorandum item); (ii) a revaluation of NBT non-monetary gold; (iii) a write-off of cotton sector loans; and (iv) a revaluation of MDRI debt relief, based on exchange rate movements. As a whole, however, the revisions represent a significant improvement in the clarity of the balance sheet and is more closely in line with IFRS. 
which contributed to high reserve money growth and slippage on the NIR target in June and thereafter. Key steps include:

- $\quad$ A significant reduction in NBT liquidity loans to commercial banks in the fourth quarter-beyond what was envisioned in the original program (from an average of SM 157 million to an average of SM 100 million). ${ }^{9}$

- A commitment not to withdraw additional funds from NBT Roghun-related deposits for the remainder of 2011.

- $\quad$ A sizeable issuance of central bank bills to mop up liquidity (net issuance expanded from SM 3 million at end-June to SM 100 million by end-September 2011).

- $\quad$ An increase in the $\mathrm{NBT}$ refinancing rate by 100 basis points (bringing the cumulative policy rate increase to $200 \mathrm{bps}$ since October 2010.

16. Fiscal tightening. While off-budget operations (particularly the transfer of Roghun deposits out of the NBT) contributed more than budgetary spending to high money growth, the central government budget must bear part of the adjustment burden. Given the need to ensure sufficient social spending, and the difficulty in terminating or suspending capital expenditures in the last quarter, the authorities agreed to fully execute the budget, but to save over-performance on revenues, such that the target for the 2011 fiscal balance would be tightened from a deficit of 1 percent of GDP to a deficit of 0.6 percent of GDP. The authorities have also committed to save any additional over-performance, with a view to controlling liquidity and minimizing the drawdown of fiscal buffers.

\section{Structural measures have been added to reduce the risk of future policy}

slippages. In addition to the quantitative measures listed above, the authorities have undertaken the following measures to strengthen macroeconomic management.

- $\quad$ A rules-based mechanism to determine the lending rate for liquidity loans was introduced in November, thereby completing a prior action for the fifth review and effectively creating a penalty rate for such loans. This should reduce the financial incentive for their use, and reinforce the position of the NBT as lender of last resort. ${ }^{10}$

\footnotetext{
${ }^{9}$ As evidence of the authorities' commitment, the stock of outstanding liquidity loans as of end-September and end-October 2011 was SM 103 million and SM 85 million, respectively.

${ }^{10}$ The mechanism is such that the interest rate on liquidity loans is set at the average commercial bank lending rate of the preceding month plus a margin of not less than $200 \mathrm{bps}$. To enhance transparency, this rate is also published on the NBT's website. A lasting reduction in liquidity support will require an end to directed lending, stronger bank management and supervision, but introduction of the penalty rate will at least reduce financial incentives to use NBT funds.
} 
A senior member of the MOF has been appointed-as prior action for completion of the fifth review - as an observer to the NBT's monetary policy meetings, with a view to sharing more timely information on the expenditure plans of the Roghun hydropower project and sources of financing - thus filling an information gap and enhancing prospects for effective liquidity management.

Detailed expenditure plans for Roghun (including import content and foreign exchange requirements) for the remainder of 2011 and 2012 will be provided to IMF staff with a view better assessing the macroeconomic impact of spending on the project. These plans will be reviewed again at the time of the mission for the sixth review, and in light of new developments with respect to ongoing feasibility studies.

\section{B. Policies for $\mathbf{2 0 1 2}$}

\section{Two years of strong economic growth since the crisis are encouraging, but the} outlook for 2012 is nonetheless uncertain. While recent GDP growth has exceeded expectations, downside risks - particularly from a potential global or regional slow-downhave increased in recent months (see Box 1). Real GDP growth for 2012 is projected at 6 percent, and inflation is expected to decline gradually, in line with global food and fuel prices. However, the systemic risks noted above, together with the potential for a recurrence of other chronic shocks (drought, natural disasters, and regional trade disputes), argue for fiscal consolidation, a forward looking monetary policy, and exchange rate flexibility together with structural reforms to facilitate private sector-led growth.

\section{The fiscal deficit for 2012 (excluding PIP) will be limited to 0.5 percent of GDP.}

Staff emphasized the need for a gradual shift back to fiscal balance or small surpluses, given the drawdown of fiscal buffers in response to the crisis and the need to create fiscal space to deal with potential quasi-fiscal liabilities stemming from financial sector and state enterprise reform. The budget for 2012 also reflects a continued shift in the composition of expenditure, with a heavier emphasis on wages and salaries (which remain low, even by regional levels) and social spending. ${ }^{11}$ Staff view the deficit target as consistent with medium-term fiscal and debt sustainability, but emphasized that any over-performance should be saved given the need to repair buffers as a cushion against heightened risk of a global slowdown or other exogenous shocks. The authorities generally agreed, but cited the need for a gradual approach that would accommodate social sector spending and critical infrastructure projects. Staff also argued that effective macroeconomic management should involve a broader definition of the fiscal deficit - to capture such key enterprises as Roghun given the macroeconomic and financial implications of spending by such enterprises.

\footnotetext{
${ }^{11}$ Social spending beyond 2012 will be set in the context of a new poverty reduction strategy for 2013-15, which is currently being drafted in cooperation with key donors.
} 


\section{Box 1: Global Uncertainties-Downside Risks for Tajikistan}

A global downturn would impact Tajikistan principally through declining remittances and lower exports and FDI, partly offset by gains in terms of trade owing to weakening food and fuel prices. As a result, growth is projected to slow down significantly. Of particular concern would be the impact on the poor, where food inflation has already decreased the purchasing power of households. The external balances would likely improve over the short run, but fiscal pressures would rise. Risks of direct financial contagion are likely minimal, as the financial sector is comparatively underdeveloped and isolated.

\section{Key assumptions:}

- $\quad$ Oil prices drop to US\$55 in 2012, and recover to US $\$ 70$ in 2013 . Food prices decline by 15 percent in 2012 and increase by 10 percent in 2013 .

- Lower global growth and oil prices are assumed to depress growth in Russia to -2 percent in 2012 with a slow recovery starting in 2013 (see adverse scenario presented in EBS 11/294).

\section{Impact on Tajikistan}

Real GDP growth falls. A decline in global growth and remittances would lower domestic income.

Construction and industrial production would shrink. As non-performing loans rise, domestic credit growth would slow. But lower commodity prices facilitate a sharp decline in inflation.

External accounts improve. The current account balance is projected to improve throughout the projection period compared to the baseline. Weaker growth, lower remittances and declining oil and food prices reduce imports sharply.

Fiscal deficit expands. Lower growth and imports would negatively impact government tax revenue. While manageable in the short-run by drawing-down fiscal buffers expenditure adjustment would be required from 2013 onwards to maintain fiscal and debt sustainability.

Financial stress: Stress tests conducted on September 2011 banking sector data suggest that under a severe shock, the capital adequacy ratio of the banking system would decline to 16.7 percent. ${ }^{1}$ While the system remains above the minimum CAR, selected banks would likely require recapitalization. In case of a deposit run three banks would face liquidity shortfalls.
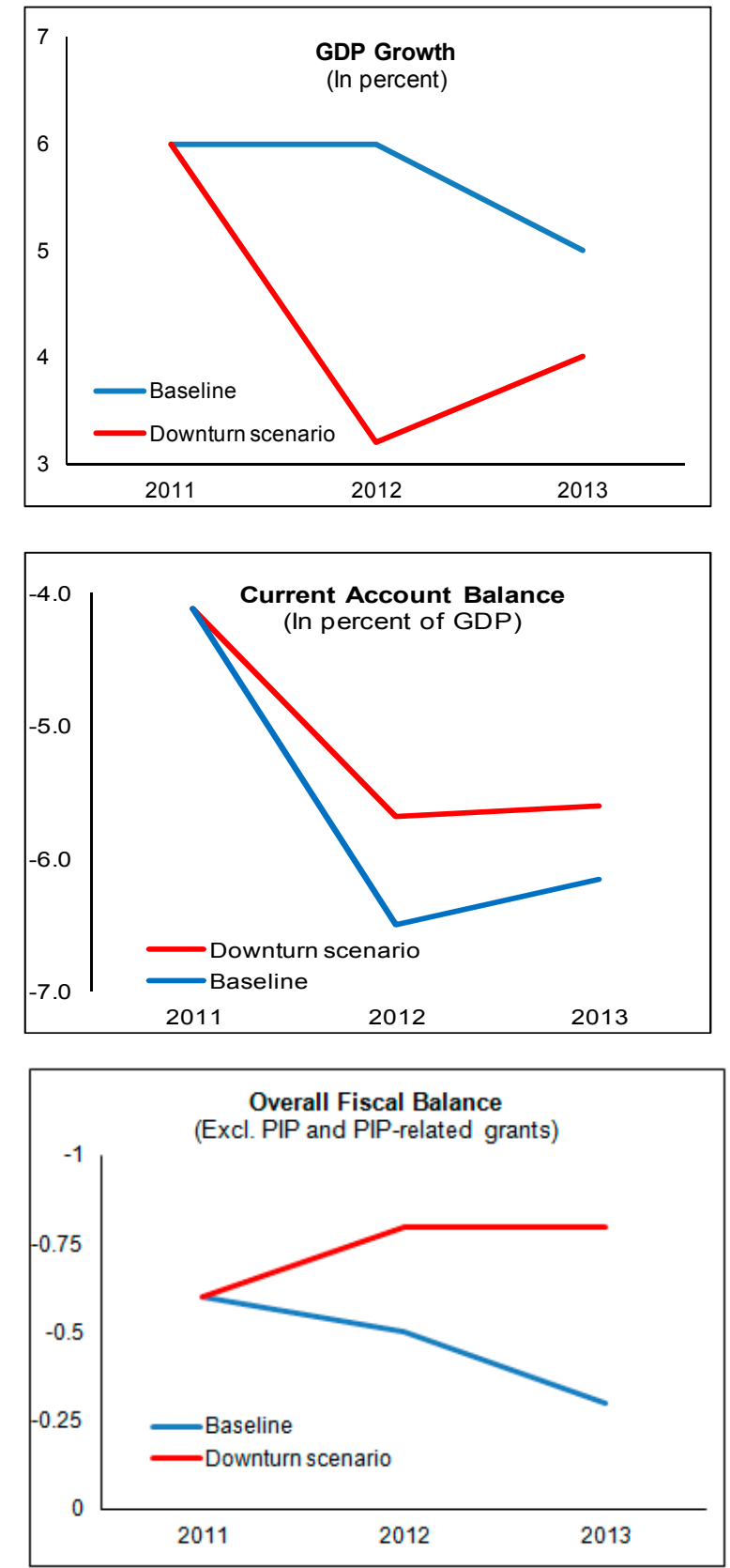

The risk of another global crisis highlights the importance of rebuilding fiscal buffers and international reserves, which would enable Tajikistan to more easily absorb any adverse shocks.

\footnotetext{
${ }^{1}$ Stress tests assume: a uniform two category migration of 18 percent of loans in each credit risk category and unrealizable collateral; deposit run based on a daily withdrawal of 10 percent of sight and term deposits for five days assuming that 80 percent of liquid assets and 1 percent of other assets can be converted into cash daily.
} 
20. Monetary policy will continue to target reserve money, while allowing for sufficient exchange rate flexibility to facilitate external adjustment. The mission emphasized the need for a conservative monetary policy given the risk of spillovers into core inflation and entrenched expectations, as well as to avoid downward pressure on the exchange rate. Given downside risks to global growth but stickiness in global commodity prices, the mission emphasized the need for vigilance and a forward-looking approach to monetary policy. The authorities agreed in principle, but also pointed to continued liquidity needs in the economy, as evidenced by strong demand for NBT liquidity loans. The mission agreed on the need for sufficient liquidity, but emphasized that in 2012, the NBT should focus on its core mandate of price stability, and that demands for liquidity support would likely diminish if directed lending were curtailed and the terms of liquidity loans maintained on a penalty basis.

21. Structural reforms for the remainder of the program focus on measures to fulfill the agenda set out at the beginning of the ECF in 2009 - related to transparency and public financial management-and recent efforts with respect to tax policy. Specifically, the authorities have committed to (i) complete a draft of the new tax code, in line with IMF recommendations by March 2012 (benchmark); (ii) complete and publish the financial audit of Roghun OJSC by March 2012 (benchmark); and (iii) implement a Treasury Single Account (TSA) at the republican level by April 2012 (a benchmark originally slated for December 2010, which was delayed for technical reasons).

\section{Program Risks}

22. Risks to the program remain numerous. As a land-locked economy with very limited domestic resources, Tajikistan remains vulnerable to external shocks from a variety of sources. Developments with respect to global/regional growth, international food and fuel prices, regional trade disputes, and climatic conditions can make or break economic outcomes and likely represent the most pressing risks. Institutional capacity remains limited, and in this context the risk of policy missteps remains relatively high. The persistence of such practices as directed lending, quasi-fiscal operations, insufficient financial discipline for large enterprises, and lack of coordination on macroeconomic policies between key agencies are problematic. NBT liquidity loans, Roghun spending, and continued arrears in state enterprises are key examples. Looking ahead, there are also risks to program targets and objectives given the convergence of (i) quasi-fiscal liabilities that have built up in the financial and state enterprise sectors, and (ii) increasing efforts to subject these sectors to real financial constraints and tighter supervision.

\section{STAFF APPRAisal}

23. Economic activity in Tajikistan has proven resilient to shocks in 2011, but vulnerabilities remain. Stronger-than-expected performance in agriculture has ameliorated food security concerns and likely contributed to the gradual downward path of headline 
inflation. The continued growth of inward remittances has helped to support overall economic recovery from the crisis, as has the recent surge in construction activity. How much of this can be carried over into 2012, however, is uncertain. Remittances depend strongly on economic growth in neighboring countries - particularly Russia — and downside risks to global prospects have worsened considerably in the past six months. Construction activity also depends at least in part on these flows, and may also have received a one-off boost from activities surrounding the $20^{\text {th }}$ anniversary celebrations in September.

\section{Mixed program performance reflects external shocks, oversights in policy} coordination, and underlying structural weaknesses. The increase in Russian export taxes on refined fuels was a significant shock - with an immediate negative impact on the balance of payments and the foreign exchange market. The decision to intervene, while simultaneously allowing the somoni to depreciate, was likely the right choice given the need to mitigate the impact on inflation and the relatively low level of confidence in the domestic currency. Nevertheless, the impact on the key program objective of boosting the NBT's limited reserve cushion is regrettable. Pressure on the balance of payments was likely exacerbated, however, by fiscal and quasi-fiscal spending on Roghun and the $20^{\text {th }}$ anniversary celebrations (both of which have a heavy import content) - also contributing to a rapid rise in reserve money growth through August, which is a concern given the increase in core inflation. These developments - along with the associated rise in liquidity loans - reflect gaps in policy coordination and macroeconomic management that need to be redressed going forward.

\section{The authorities' commitment to tighten monetary and fiscal policies in the last} part of 2011 is welcome, as are supporting administrative measures. Of particular importance are the revised fiscal target and the imposition of a penalty rate on NBT liquidity loans. Greater coordination on liquidity management between the NBT and the MOF will be essential, however, as will a broader view of fiscal policy, which includes the impact of Roghun spending - a potential macroeconomic risk highlighted by staff since the financing campaign of 2010. Work has been progressing steadily on bringing greater transparency to quasi-fiscal operations over the life of the current ECF - including audits of key firms, regular monitoring of their financial operations in the SOE unit in the ministry of finance, and public reporting on the financial operations of Roghun. Staff is of the view, however, that risks from quasi-fiscal operations remain, and that the next step should be a forwardlooking integration of quasi-fiscal operations into the official budget. Staff is also of the view, that a lasting solution to the monetary and liquidity management problems evident this year will rest on a cessation of directed lending, and a strengthening of financial sector supervision.

\section{The progress on structural reforms stands in contrast to the slippage on}

quantitative targets. Completion of key audits, improvements in transparency, progress toward recapitalization of the NBT, an ambitious approach to tax policy reform, and implementation of the action plan on financial sector reform are laudable achievements. Staff 
strongly supports the authorities' actions in these areas - some of which (such as the Roghun shareholder's meeting) were outside formal program conditionality. At the same time, the length of delay in completing the Roghun OJSC audit is regrettable (albeit understandable from a technical point of view). Staff urges the authorities to complete this benchmark as quickly as possible. Long delays in completing the audit of the NBT's 2010 financial statements also indicate continued capacity problems at the NBT, and uneven cooperation among government agencies. Continued efforts are needed to address these problems.

\section{Continued provision of technical assistance is critical to ensure successful} outcomes. Given the structural nature of many of the macroeconomic and policy challenges faced by the authorities, the provision of technical assistance has been and will remain key. Staff has continually sought to funnel practical, well-targeted TA in support of ongoing reforms with a high chance of success. Continued donor support for these efforts is essential.

Staff supports the authorities' request for completion of the fifth review under the ECF arrangement and the sixth disbursement in the amount of SDR 13.045 million. In this context, it also supports the authorities' request for waivers of nonobservance of the performance criteria on net international reserves, and wage and pension arrears. Staff also supports modification of end-December 2011 performance criteria on net domestic assets, net international reserves, and the budget deficit, as well as the indicative targets on tax revenue and NBT liquidity loans. 
Table 1. Tajikistan: Selected Economic Indicators, 2009-12

\begin{tabular}{|c|c|c|c|c|}
\hline & $\begin{array}{r}2009 \\
\text { Act. }\end{array}$ & $\begin{array}{r}2010 \\
\text { Act. }\end{array}$ & $\begin{array}{r}2011 \\
\text { Proj. }\end{array}$ & $\begin{array}{r}2012 \\
\text { Proj. }\end{array}$ \\
\hline \multicolumn{5}{|c|}{ (Annual percent change; unless otherwise indicated) } \\
\hline \multicolumn{5}{|l|}{ National accounts } \\
\hline Real GDP & 3.9 & 6.5 & 6.0 & 6.0 \\
\hline GDP deflator (cumulative) & 12.7 & 12.5 & 19.4 & 15.0 \\
\hline Headline CPI inflation (end-of-period) & 5.0 & 9.8 & 13.4 & 9.0 \\
\hline Headline CPI inflation (period average) & 6.5 & 6.5 & 13.0 & 10.6 \\
\hline Core CPI inflation (period average) & 5.9 & 6.0 & 5.7 & 5.2 \\
\hline \multicolumn{5}{|c|}{ (In percent of GDP; unless otherwise indicated) } \\
\hline \multicolumn{5}{|l|}{ Investment and saving $1 /$} \\
\hline Investment & 18.8 & 17.9 & 18.2 & 19.2 \\
\hline Of which: Fixed capital investment & 14.3 & 12.9 & 13.2 & 14.7 \\
\hline Government & 13.3 & 10.9 & 10.2 & 10.7 \\
\hline Private & 1.0 & 2.0 & 3.0 & 4.0 \\
\hline Gross national savings & 12.8 & 20.0 & 14.1 & 12.7 \\
\hline Public & 7.8 & 7.2 & 7.0 & 7.6 \\
\hline Private & 5.0 & 12.8 & 7.1 & 5.1 \\
\hline \multicolumn{5}{|l|}{ General government finances } \\
\hline Revenue and grants & 23.4 & 23.2 & 23.5 & 24.1 \\
\hline Of which: Tax revenue & 17.6 & 18.0 & 18.4 & 18.4 \\
\hline Expenditure and net lending & 28.9 & 26.9 & 26.7 & 27.1 \\
\hline Of which: Current & 14.6 & 15.0 & 16.0 & 16.4 \\
\hline Capital & 13.3 & 10.9 & 10.2 & 10.7 \\
\hline Overall balance (excl. PIP and stat. discrepancy) & -0.5 & -0.4 & -0.6 & -0.5 \\
\hline Overall balance (incl. PIP and stat. discrepancy) & -5.4 & -3.7 & -3.1 & -3.1 \\
\hline Domestic financing & 1.3 & -0.4 & 1.0 & 1.4 \\
\hline External financing & 4.2 & 4.1 & 2.1 & 1.7 \\
\hline Overall balance (incl. PIP and stat. discrepancy) + Roghun OJSC 2/ & -5.4 & -1.1 & -4.3 & -5.7 \\
\hline Total public and publicly-guaranteed debt & 34.7 & 36.5 & 33.3 & 35.3 \\
\hline \multicolumn{5}{|l|}{ Monetary sector } \\
\hline Broad money (12-month percent change) & 39.6 & 26.2 & 23.2 & 23.0 \\
\hline Reserve money (12-month percent change) & 39.2 & 15.8 & 27.4 & 16.1 \\
\hline Credit to private sector (12-month percent change) $6 /$ & -2.2 & -15.2 & 8.7 & 12.6 \\
\hline Velocity of broad money (eop) & 5.1 & 4.9 & 5.0 & 5.0 \\
\hline Refinancing rate (eop, in percent) $7 /$ & 8.0 & 8.25 & 10.0 & $\ldots$ \\
\hline
\end{tabular}

(In percent of GDP; unless otherwise indicated)

External sector $3 /$

Exports of goods and services (U.S. dollar, percent change)

Imports of goods and services (U.S. dollar, percent change)

Current account balance

Total public and publicly guaranteed external debt

Gross official reserves (in U.S. dollars) 4/

In months of next year's imports 5/

In percent of broad money

\begin{tabular}{|c|c|c|c|}
\hline-12.7 & 32.3 & 21.7 & 2.6 \\
\hline-26.7 & 9.4 & 42.8 & 9.0 \\
\hline-5.9 & 2.1 & -4.1 & -6.5 \\
\hline 34.0 & 34.4 & 31.3 & 33.1 \\
\hline 278 & 476 & 582 & 652 \\
\hline 1.2 & 1.4 & 1.5 & 1.6 \\
\hline 16.6 & 21.4 & 20.0 & 16.7 \\
\hline 20,623 & 24,705 & 31,256 & 38,089 \\
\hline 4,977 & 5,642 & 6,748 & 7,473 \\
\hline 75.0 & 69.5 & $\ldots$ & $\cdots$ \\
\hline 97.2 & 92.1 & $\ldots$ & $\cdots$ \\
\hline 4.14 & 4.38 & $\ldots$ & \\
\hline
\end{tabular}

Memorandum items:

Nominal GDP (in millions of somoni)

Nominal GDP (in millions of U.S. dollars)

Nominal effective exchange rate (Index 2000 $=100$ )

Real effective exchange rate (Index 2000=100)

Average exchange rate (somoni per U.S. dollar)

Sources: Data provided by the Tajikistan authorities, and Fund staff estimates.

1/ Private investment and savings are estimates. Investment includes changes in stocks.

2/ For consolidation, Roghun equity sales in 2010-11 are added to general government revenue. Over 2011-15, it is assumed that the remaining financing needs of Roghun OJSC are met from external sources at consessional terms.

$3 /$ Receipts from aluminium exports under the tolling arrangements are booked as services exports.

4/ Includes SDR 81.2 million allocation in Q3 2009.

5/ Excluding electricity, which is on barter basis, and imports related to projects financed with loans from China.

6/ Decline in 2010 is due to resolution of Kredit Invest (KI) carrying large nonperfoming loans to the cotton sector.

7/ For 2011, as of October 31. 
Table 2. Tajikistan: General Government Operations, 2009-12 (In millions of somoni; unless otherwise indicated)

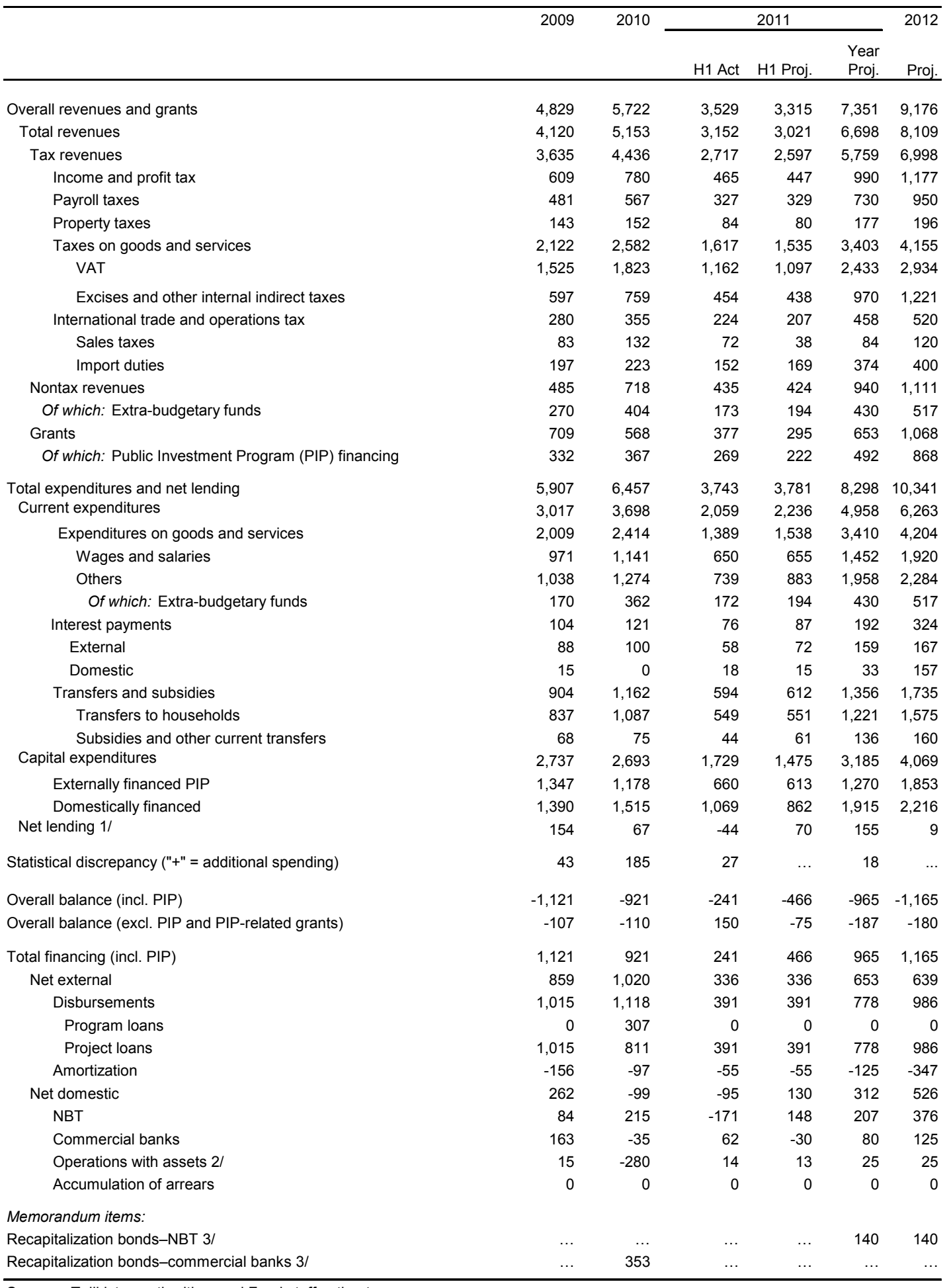

Sources: Tajikistan authorities, and Fund staff estimates.

1/ Includes 140 million somoni lending to the cotton sector in 2008 and 180 million somoni in 2009.

2/ Includes transfer of MDRI deposits to the NBT in 2010 towards NBT recapitalization.

$3 /$ Issuance to compensate the NBT and banks for losses related to cotton lending as part of cotton debt resolution. 
Table 3. Tajikistan: General Government Operations, 2009-12 (In percent of GDP; unless otherwise indicated)

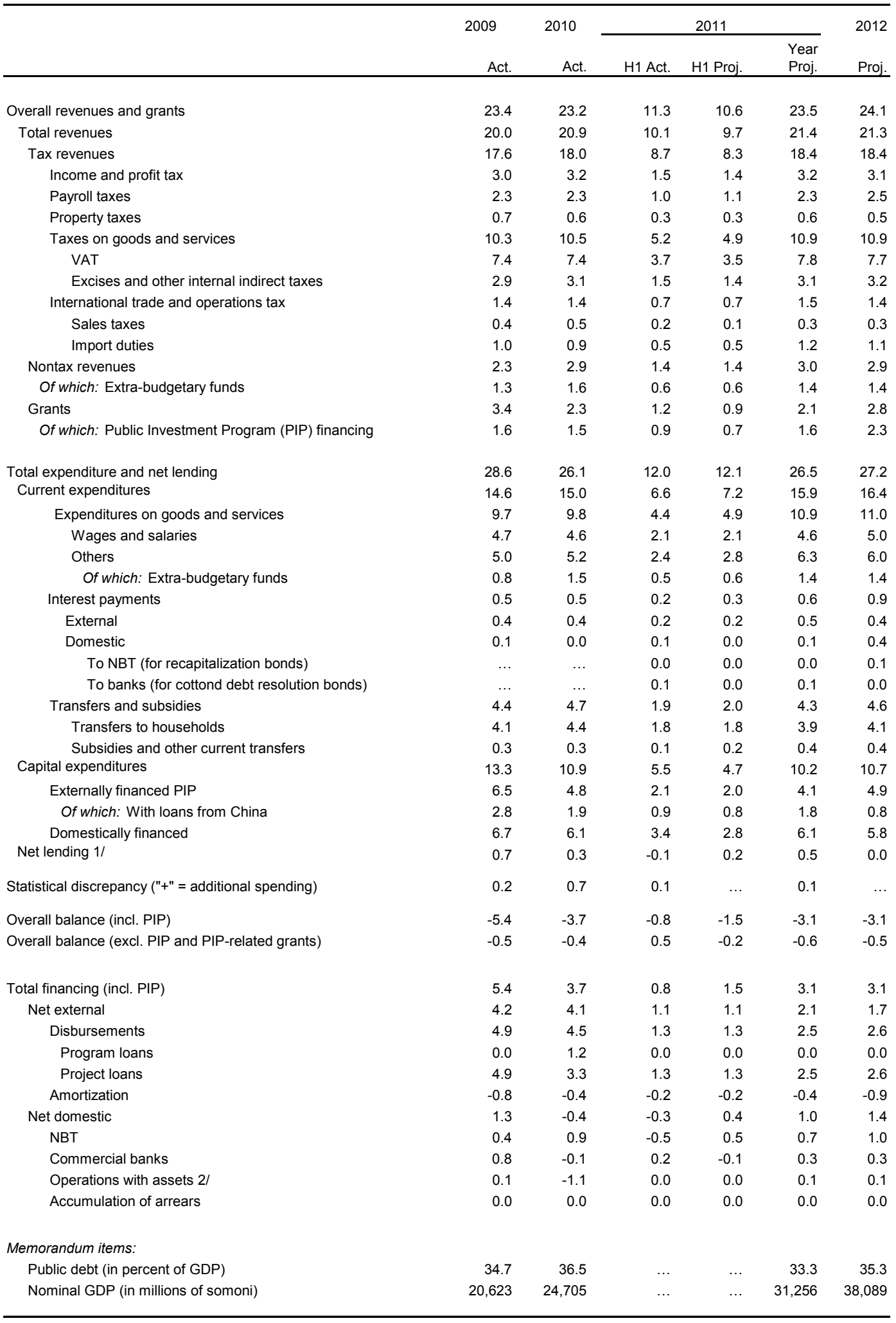

Sources: Tajikistan authorities, and Fund staff estimates.

1/ Includes 140 million somoni lending to the cotton sector in 2008 and 180 million somoni in 2009.

2/ Includes transfer of MDRI deposits to the NBT in 2010 towards NBT recapitalization. 
Table 4. Tajikistan: Accounts of the National Bank Tajikistan, 2009-12 (End-of-period stock; unless otherwise specified)

\begin{tabular}{|c|c|c|c|c|c|c|c|}
\hline & \multirow{2}{*}{$\begin{array}{c}2009 \\
\text { Dec. } \\
\text { Act. }\end{array}$} & \multirow{2}{*}{$\begin{array}{l}2010 \\
\text { Dec. } \\
\text { Act. }\end{array}$} & \multicolumn{4}{|c|}{2011} & \multirow{2}{*}{$\begin{array}{l}2012 \\
\text { Dec. } \\
\text { Proj. }\end{array}$} \\
\hline & & & $\begin{array}{c}\text { March } \\
\text { Act. }\end{array}$ & $\begin{array}{c}\text { June } \\
\text { Act. }\end{array}$ & $\begin{array}{l}\text { Sept. } \\
\text { Act. }\end{array}$ & $\begin{array}{l}\text { Dec. } \\
\text { Proj. }\end{array}$ & \\
\hline & \multicolumn{6}{|c|}{ (In millions of somoni) } & \\
\hline Net foreign assets & 661 & 1,825 & 1,942 & 2,056 & 2,294 & 2,413 & 2,872 \\
\hline Of which: Net international reserves $1 / 2$ / & 1,034 & 1,650 & 1,752 & 1,873 & 2,020 & 2,131 & 2,566 \\
\hline Net domestic assets & 1,922 & 1,164 & 917 & 1,066 & 1,158 & 1,394 & 1,550 \\
\hline Net credit to general government & -865 & -994 & $-1,262$ & $-1,067$ & $-1,028$ & -568 & -217 \\
\hline General government & -860 & -645 & -894 & -816 & -898 & -438 & -62 \\
\hline Roghun JSC & -5 & -349 & -368 & -252 & -130 & -130 & -155 \\
\hline Credit to the private sector $3 /$ & 1,687 & 945 & 946 & 878 & 782 & 662 & 651 \\
\hline \multicolumn{7}{|l|}{ Of which: } & 39 \\
\hline NBT bills & 0 & -3 & -7 & -3 & -100 & -201 & -212 \\
\hline Liquidity loans & 164 & 186 & 199 & 149 & 103 & 100 & 100 \\
\hline Credit to nonbank institutions & 110 & 611 & 579 & 598 & 606 & 611 & 611 \\
\hline Other items, net & 1,100 & 1,213 & 1,233 & 1,255 & 1,405 & 1,300 & 1,116 \\
\hline Of which: Retained profits and provisions (+ losses) & 2,271 & 1,512 & 1,587 & 1,848 & 1,785 & $\ldots$ & $\ldots$ \\
\hline Reserve money & 2,583 & 2,990 & 2,859 & 3,121 & 3,452 & 3,807 & 4,422 \\
\hline Currency in circulation & 2,041 & 2,421 & 2,448 & 2,571 & 2,934 & 3,007 & 3,538 \\
\hline Bank reserves & 533 & 565 & 403 & 546 & 513 & 798 & 883 \\
\hline Required reserves & 181 & 234 & 260 & 285 & 322 & 378 & 476 \\
\hline \multirow[t]{2}{*}{ Other bank deposits } & 353 & 331 & 143 & 261 & 191 & 420 & 406 \\
\hline & \multicolumn{7}{|c|}{ (12-month growth in percent of reserve money) } \\
\hline Reserve money & 39.2 & 15.8 & 28.5 & 37.3 & 27.6 & 27.4 & 16.1 \\
\hline Net foreign assets & 21.4 & 45.1 & 52.3 & 49.1 & 33.7 & 19.7 & 12.1 \\
\hline Net domestic assets & 17.8 & -29.3 & -23.8 & -11.8 & -6.1 & 7.7 & 4.1 \\
\hline Net credit to general government & 4.5 & -5.0 & 4.0 & 9.2 & 8.0 & 14.2 & 9.2 \\
\hline Credit to the private sector & -36.2 & -28.7 & -71.7 & -79.5 & -79.8 & -9.5 & -0.3 \\
\hline Of which: NBT bills & 0.0 & -0.1 & -0.3 & 2.6 & -3.4 & -6.6 & -0.3 \\
\hline Other items net & 49.4 & 4.4 & 44.0 & 58.6 & 65.7 & 2.9 & -4.8 \\
\hline \multicolumn{8}{|l|}{ Memorandum items: } \\
\hline Net international reserves (in millions of U.S.dollars) & 236 & 375 & 392 & 401 & 425 & 435 & 484 \\
\hline Net international reserves (percent of broad money) & 25.6 & 32.5 & 30.8 & 29.6 & 29.0 & 34.0 & 33.6 \\
\hline Official exchange rate (somoni/U.S. dollars) & 4.37 & 4.40 & 4.47 & 4.67 & 4.75 & $\ldots$ & $\cdots$ \\
\hline Guarantee settlement (in millions of U.S. dollars) & 38 & $\ldots$ & $\ldots$ & $\ldots$ & $\ldots$ & $\ldots$ & $\ldots$ \\
\hline
\end{tabular}

Sources: National Bank of Tajikistan, and Fund staff estimates.

1/ Includes SDR 81.2 million allocation in Q3 2009.

2/ Excludes nonmonetary gold.

3/ Decrease in 2010 reflects the write-off of credits to KI. 
Table 5. Tajikistan: Monetary Survey, 2009-12

\begin{tabular}{|c|c|c|c|c|c|c|c|c|c|c|}
\hline & \multirow{2}{*}{$\begin{array}{l}2009 \\
\text { Dec. } \\
\text { Act. }\end{array}$} & \multicolumn{3}{|c|}{2010} & \multirow{2}{*}{$\begin{array}{l}2010 \\
\text { Dec. } \\
\text { Act. }\end{array}$} & \multicolumn{4}{|c|}{2011} & \multirow{2}{*}{$\begin{array}{l}2012 \\
\text { Dec. } \\
\text { Proj. }\end{array}$} \\
\hline & & $\begin{array}{c}\text { March } \\
\text { Act. }\end{array}$ & $\begin{array}{l}\text { June } \\
\text { Act. }\end{array}$ & $\begin{array}{l}\text { Sept. } \\
\text { Act. }\end{array}$ & & $\begin{array}{c}\text { March } \\
\text { Act. }\end{array}$ & $\begin{array}{l}\text { June } \\
\text { Act. }\end{array}$ & $\begin{array}{l}\text { Sept. } \\
\text { Act. }\end{array}$ & $\begin{array}{l}\text { Dec. } \\
\text { Proj. }\end{array}$ & \\
\hline & \multicolumn{10}{|c|}{ (In millions of somoni, end-of-period stock; unless otherwise specified) } \\
\hline Net foreign assets & 700 & 893 & 989 & 1,487 & 1,814 & 1,902 & 1,925 & 2,213 & 2,332 & 2,791 \\
\hline National Bank of Tajikistan 1/ & 661 & 779 & 940 & 1,382 & 1,825 & 1,942 & 2,056 & 2,294 & 2,413 & 2,872 \\
\hline Commercial banks & 39 & 115 & 49 & 105 & -11 & -40 & -131 & -81 & -81 & -81 \\
\hline Net domestic assets & 3,378 & 2,845 & 3,060 & 3,103 & 3,291 & 3,842 & 4,484 & 4,845 & 4,025 & 4,937 \\
\hline Net credit to general government (incl. Roghun OJSC) & -797 & $-1,576$ & $-1,199$ & $-1,056$ & -814 & $-1,099$ & -826 & -833 & -309 & 268 \\
\hline National Bank of Tajikistan & -865 & $-1,350$ & $-1,277$ & $-1,245$ & -994 & $-1,262$ & $-1,067$ & $-1,028$ & -568 & -217 \\
\hline Commercial banks & 68 & -225 & 78 & 189 & 179 & 163 & 241 & 195 & 259 & 484 \\
\hline Credit to the private sector & 4,429 & 3,872 & 3,465 & 3,657 & 3,755 & 3,915 & 4,192 & 4,456 & 4,083 & 4,598 \\
\hline Other items, net & -254 & 549 & 794 & 502 & 350 & 1,027 & 1,118 & 1,222 & 250 & 72 \\
\hline Broad money (excl. bills payable) & 4,039 & 3,704 & 4,007 & 4,538 & 5,078 & 5,695 & 6,336 & 6,975 & 6,273 & 7,645 \\
\hline Somoni broad money & 2,559 & 2,212 & 2,274 & 2,824 & 3,179 & 3,554 & 3,867 & 4,130 & 3,715 & 4,527 \\
\hline Currency outside banks & 1,776 & 1,524 & 1,548 & 1,873 & 2,011 & 2,006 & 2,250 & 2,652 & 2,362 & 2,734 \\
\hline Deposits & 783 & 689 & 726 & 951 & 1,169 & 1,548 & 1,618 & 1,478 & 1,353 & 1,793 \\
\hline Foreign currency deposits & 1,480 & 1,492 & 1,734 & 1,714 & 1,899 & 2,141 & 2,469 & 2,844 & 2,558 & 3,118 \\
\hline Broad money (excl. bills payable) & 38.9 & 31.5 & 27.0 & 28.2 & 25.7 & 53.7 & 58.1 & 53.7 & 23.5 & 21.9 \\
\hline Net foreign assets & 32.9 & 40.3 & 32.8 & 30.1 & 27.6 & 27.2 & 23.3 & 16.0 & 10.2 & 7.3 \\
\hline National Bank of Tajikistan & 13.6 & 19.3 & 20.5 & 28.4 & 28.8 & 31.4 & 27.8 & 20.1 & 11.6 & 7.3 \\
\hline Commercial banks & 19.2 & 21.0 & 12.3 & 1.8 & -1.2 & -4.2 & -4.5 & -4.1 & -1.4 & 0.0 \\
\hline Net domestic assets (incl. bills payable) & 6.8 & -8.2 & -6.3 & -2.7 & -2.2 & 26.9 & 35.5 & 38.4 & 14.5 & 14.5 \\
\hline Net credit to general government & 10.1 & -11.5 & -2.3 & 2.7 & -0.4 & 12.9 & 9.3 & 4.9 & 10.0 & 9.2 \\
\hline Credit to the private sector & -3.5 & -27.8 & -50.6 & -46.0 & -16.7 & 1.2 & 18.1 & 17.6 & 6.5 & 8.2 \\
\hline Other items, net & 0.1 & 31.2 & 46.7 & 40.6 & 15.0 & 12.9 & 8.1 & 15.9 & -2.0 & -2.8 \\
\hline Bills payable & 0.7 & 0.6 & -0.5 & -0.8 & -0.3 & 0.4 & 0.8 & 0.7 & 1.1 & 0.0 \\
\hline \multicolumn{11}{|l|}{ Memorandum items: } \\
\hline Credit to the private sector (12-month percent change) & -2.2 & -16.8 & -31.6 & -30.8 & -15.2 & 1.2 & 18.1 & 17.6 & 8.7 & 12.6 \\
\hline Deposit dollarization (in percent) & 65.6 & 68.5 & 70.5 & 64.3 & 61.9 & 58.1 & 60.4 & $\ldots$ & $\ldots$ & $\ldots$ \\
\hline Velocity & 5.1 & $\ldots$ & $\ldots$ & $\ldots$ & 4.9 & $\ldots$ & $\ldots$ & $\ldots$ & 5.0 & 5.0 \\
\hline Money multiplier & 1.6 & & & & 1.7 & $\ldots$ & $\ldots$ & $\ldots$ & 1.6 & 1.7 \\
\hline
\end{tabular}

Sources: National Bank of Tajikistan, and Fund staff estimates.

1/ Revised from EBS/09/43 to exclude nonmonetary gold.

2/ Liabilities to cotton financiers related to domestic cotton financing. 
Table 6. Tajikistan: Balance of Payments, 2009-16 (In millions of U.S. dollars; unless otherwise indicated)

\begin{tabular}{|c|c|c|c|c|c|c|c|c|}
\hline & 2009 & 2010 & 2011 & 2012 & 2013 & 2014 & 2015 & 2016 \\
\hline & Act. & Act. & Proj. & Proj. & Proj. & Proj. & Proj. & Proj. \\
\hline Current account & -295 & 120 & -274 & -486 & -516 & -513 & -563 & -544 \\
\hline Balance on goods and services $1 /$ & $-1,958$ & $-1,969$ & $-3,022$ & $-3,372$ & $-3,607$ & $-3,836$ & $-4,141$ & $-4,406$ \\
\hline Balance on goods & $-1,980$ & $-1,955$ & $-2,860$ & $-3,382$ & $-3,601$ & $-3,834$ & $-4,140$ & $-4,411$ \\
\hline Exports & 408 & 594 & 587 & 575 & 632 & 686 & 734 & 788 \\
\hline Imports & $-2,388$ & $-2,549$ & $-3,447$ & $-3,957$ & $-4,234$ & $-4,520$ & $-4,874$ & $-5,200$ \\
\hline Balance on services & 22 & -14 & -162 & 10 & -5 & -2 & -1 & 5 \\
\hline Balance on income & -71 & -79 & -56 & -58 & -65 & -72 & -81 & -84 \\
\hline Balance on transfers & 1,735 & 2,167 & 2,803 & 2,944 & 3,155 & 3,396 & 3,659 & 3,946 \\
\hline Of which: $M$ igrants' remittances, net & 1,622 & 2,040 & 2,697 & 2,854 & 3,083 & 3,332 & 3,601 & 3,892 \\
\hline Capital and financial account & 382 & -80 & 339 & 335 & 406 & 437 & 501 & 687 \\
\hline Capital transfers & 120 & 84 & 106 & 170 & 75 & 58 & 51 & 70 \\
\hline Disbursements & 241 & 185 & 167 & 245 & 282 & 291 & 256 & 350 \\
\hline Of which: $P$ rojects financed by China & 137 & 108 & 85 & 105 & 150 & 150 & 150 & 150 \\
\hline Amortization & -32 & -45 & -32 & -75 & -100 & -104 & -98 & -106 \\
\hline FDI & 16 & 16 & 30 & 190 & 251 & 285 & 324 & 429 \\
\hline Commercial bank NFA (- increase) & -161 & 11 & 14 & -1 & -1 & -1 & -1 & -1 \\
\hline NBT $2 /$ & 28 & 0 & 0 & 0 & 0 & 0 & 0 & 0 \\
\hline Other capital flows and errors and omissions $3 /$ & 171 & -332 & 54 & -234 & -142 & -93 & -31 & -55 \\
\hline Overall balance & 88 & 39 & 65 & -151 & -110 & -76 & -62 & 143 \\
\hline Overall balance (excluding budget support grants) & 11 & -7 & 23 & -190 & -143 & -108 & -94 & 143 \\
\hline Financing items & -128 & -169 & -106 & -70 & -70 & -74 & -112 & -173 \\
\hline Use of international reserves (- increase) & -128 & -169 & -106 & -70 & -70 & -70 & -100 & -150 \\
\hline IMF disbursements & -15 & 0 & 0 & 0 & 0 & -4 & -12 & -23 \\
\hline Exceptional financing 4/ & 15 & 0 & 0 & 0 & 0 & 0 & 0 & 0 \\
\hline Financing gap & 117 & 176 & 84 & 260 & 213 & 183 & 206 & 30 \\
\hline World Bank 5/ & 21 & 25 & 10 & 10 & $\ldots$ & $\ldots$ & $\ldots$ & $\ldots$ \\
\hline AsDB 5/ & 40 & 10 & 20 & 25 & $\ldots$ & $\ldots$ & $\ldots$ & $\ldots$ \\
\hline EC 5/ & 16 & 11 & 12 & 4 & $\ldots$ & $\ldots$ & $\ldots$ & $\ldots$ \\
\hline Anti-crisis Fund & $\cdots$ & 70 & 0 & 40 & $\cdots$ & $\cdots$ & $\cdots$ & $\cdots$ \\
\hline Residual financing gap 6/ & $\ldots$ & $\ldots$ & $\ldots$ & 160 & 180 & 150 & 174 & $\ldots$ \\
\hline \multicolumn{9}{|l|}{ Memorandum items: } \\
\hline Nominal GDP & 4,977 & 5,642 & 6,748 & 7,473 & 8,372 & 9,503 & 10,788 & 12,248 \\
\hline Current account balance (in percent of GDP) & -5.9 & 2.1 & -4.1 & -6.5 & -6.2 & -5.4 & -5.2 & -4.4 \\
\hline Gross reserves & 278 & 476 & 582 & 652 & 722 & 792 & 892 & 1042 \\
\hline (In months of next year's imports of goods and services) $7 /$ & 1.2 & 1.4 & 1.5 & 1.6 & 1.7 & 1.7 & 1.8 & 1.9 \\
\hline Total Public and Publicly Guaranteed (PPG) external sector debt 8/ & 1,692 & 1,942 & 2,109 & 2,477 & 2,852 & 3,152 & 3,458 & 3,668 \\
\hline (In percent of GDP) & 34.0 & 34.4 & 31.3 & 33.1 & 34.1 & 33.2 & 32.1 & 29.9 \\
\hline Debt service on PPG external debt & 153 & 73 & 76 & 122 & 146 & 159 & 155 & 178 \\
\hline (In percent of exports of goods and services) & 20.3 & 7.3 & 6.2 & 9.8 & 10.8 & 10.9 & 9.9 & 10.6 \\
\hline
\end{tabular}

Sources: Tajik authorities, and Fund staff estimates.

$1 /$ Starting from 2005, the export and import figures reflect the transition to the tolling arrangement for aluminium exports.

2/ Includes SDR 82.1 million allocation to Tajikistan in Q3 2009.

$3 /$ Includes change in foreign currency balances held by residents of Tajikistan.

4/ Pakistan's government converted Tajikistan's debt into a grant.

5/ Budget support grants.

6/ The financing gap in 2012-15 includes financing for the Roghun HPP. The World Bank feasibility study, instrumental in identifying the financing, is ongoing

7/ Excluding electricity, which is on barter basis, and imports related to projects financed with loans from China.

8/ External debt is defined as debt to nonresidents. 
Table 7. Tajikistan: Financial Soundness Indicators, 2008-11

(In percent; unless otherwise indicated)

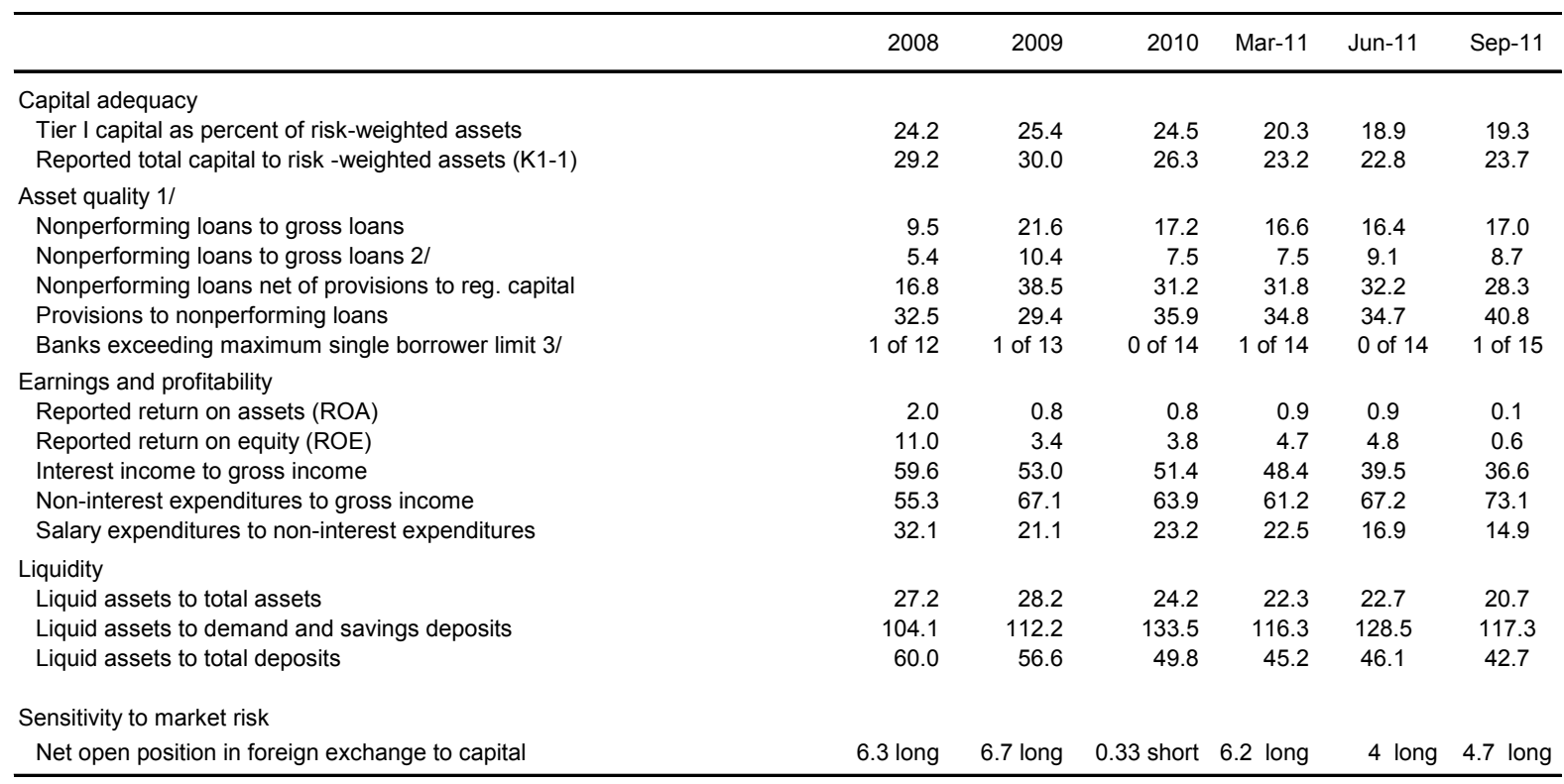

Source: National Bank of Tajikistan.

$1 /$ Nonperforming loans includes loans more than 1 day overdue.

2/ Nonperforming loans includes loans more than 30 day overdue.

3 / Maximum single borrower limit is defined as 25 percent of capital (K3-1). 
Table 8. Tajikistan: Capacity to Repay the Fund, 2010-20 /1

\begin{tabular}{|c|c|c|c|c|c|c|c|c|c|c|c|}
\hline & 2010 & 2011 & 2012 & 2013 & 2014 & 2015 & 2016 & 2017 & 2018 & 2019 & 2020 \\
\hline \multicolumn{12}{|l|}{ Existing and prospective Fund credit 1/ } \\
\hline In millions of SDRs & 65.3 & 91.4 & 104.4 & 104.4 & 101.8 & 94.0 & 79.6 & 60.0 & 39.2 & 20.9 & 7.8 \\
\hline In millions of U.S. dollars & 99.6 & 145.2 & 165.9 & 165.9 & 161.7 & 149.3 & 126.5 & 95.4 & 62.2 & 33.2 & 12.4 \\
\hline In percent of exports & 10.0 & 11.9 & 13.3 & 12.2 & 11.1 & 9.6 & 7.5 & 5.2 & 3.1 & 1.5 & 0.5 \\
\hline In percent of external debt & 3.5 & 4.7 & 4.6 & 4.0 & 3.5 & 2.9 & 2.3 & 1.6 & 1.0 & 0.5 & 0.2 \\
\hline In percent of gross reserves & 20.9 & 24.9 & 25.4 & 23.0 & 20.4 & 16.7 & 12.1 & 8.0 & 4.6 & 2.2 & 0.8 \\
\hline In percent of quota & 75.0 & 105.0 & 120.0 & 120.0 & 117.0 & 108.0 & 91.5 & 69.0 & 45.0 & 24.0 & 9.0 \\
\hline \multicolumn{12}{|l|}{ Fund obligation based on existing credit } \\
\hline In millions of SDRs & 0.0 & 0.0 & 0.2 & 0.2 & 2.8 & 8.1 & 14.6 & 15.8 & 15.8 & 13.1 & 7.9 \\
\hline In millions of U.S. dollars & 0.0 & 0.0 & 0.4 & 0.4 & 4.5 & 12.8 & 23.1 & 25.1 & 25.1 & 20.9 & 12.5 \\
\hline In percent of exports & 0.0 & 0.0 & 0.0 & 0.0 & 0.3 & 0.8 & 1.4 & 1.4 & 1.3 & 1.0 & 0.5 \\
\hline In percent of external debt & 0.0 & 0.0 & 0.0 & 0.0 & 0.1 & 0.2 & 0.4 & 0.4 & 0.4 & 0.3 & 0.2 \\
\hline In percent of gross reserves & 0.0 & 0.0 & 0.1 & 0.1 & 0.8 & 2.0 & 3.5 & 3.6 & 3.4 & 2.8 & 1.6 \\
\hline In percent of quota & 0.0 & 0.0 & 0.3 & 0.3 & 3.3 & 9.3 & 16.7 & 18.2 & 18.1 & 15.1 & 9.1 \\
\hline \multicolumn{12}{|c|}{ Fund obligation based on existing and prospective credit } \\
\hline In millions of SDRs & 0.0 & 0.0 & 0.3 & 0.3 & 2.9 & 8.1 & 14.6 & 19.8 & 21.1 & 18.4 & 13.1 \\
\hline In millions of U.S. dollars & 0.0 & 0.0 & 0.4 & 0.4 & 4.6 & 12.8 & 23.2 & 31.4 & 33.4 & 29.2 & 20.8 \\
\hline In percent of exports & 0.0 & 0.0 & 0.0 & 0.0 & 0.3 & 0.8 & 1.4 & 1.7 & 1.7 & 1.3 & 0.9 \\
\hline In percent of external debt & 0.0 & 0.0 & 0.0 & 0.0 & 0.1 & 0.2 & 0.4 & 0.5 & 0.5 & 0.5 & 0.3 \\
\hline In percent of gross reserves & 0.0 & 0.0 & 0.1 & 0.1 & 0.8 & 2.0 & 3.5 & 4.5 & 4.6 & 3.8 & 2.6 \\
\hline In percent of quota & 0.0 & 0.0 & 0.3 & 0.3 & 3.3 & 9.3 & 16.8 & 22.8 & 24.2 & 21.1 & 15.1 \\
\hline \multicolumn{12}{|l|}{ Memorandum items: } \\
\hline Gross reserves (in millions of U.S. dollars) & 476 & 582 & 652 & 722 & 792 & 892 & 1,042 & 1,192 & 1,342 & 1,492 & 1,642 \\
\hline Quota (in millions of SDRs) & 87 & 87 & 87 & 87 & 87 & 87 & 87 & 87 & 87 & 87 & 87 \\
\hline
\end{tabular}

Sources: Tajik authorities, and Fund staff estimates.

$1 /$ End of period. 
Table 9. Tajikistan: Reviews and Disbursements under the Three-Year ECF Arrangement, 2009-12

\begin{tabular}{|c|c|c|c|c|}
\hline Date & Action & $\begin{array}{l}\text { Original disbursements, } \\
\text { million SDRs }\end{array}$ & $\begin{array}{l}\text { Augmentation, } \\
\text { million SDRs }\end{array}$ & $\begin{array}{l}\text { Disbursements after } \\
\text { augmentation, million }\end{array}$ \\
\hline On May 7, 2009 & Approval of the ECF arrangement & 26.100 & $\ldots$ & 26.100 \\
\hline On or after April 15, 2010 & Completion of the first and second reviews & 26.120 & $\ldots$ & 26.120 \\
\hline On or after September 15, 2010 & Completion of the third review & 6.523 & 6.523 & 13.045 \\
\hline On or after March 15, 2011 & Completion of the fourth review & 6.523 & 6.523 & 13.045 \\
\hline On or after September 15, 2011 & Completion of the fifth review & 6.523 & 6.523 & 13.045 \\
\hline On or after March 15, 2012 & Completion of the sixth review & 6.523 & 6.523 & 13.045 \\
\hline
\end{tabular}

Source: Fund staff estimates. 


\title{
ATTACHMENT I. TAJIKISTAN: LETTER OF INTENT
}

December 22, 2011

\author{
Her Excellency \\ Ms. Christine Lagarde \\ Managing Director \\ International Monetary Fund \\ 700 19th Street, N.W. \\ Washington, DC 20431
}

\section{Dear Ms. Lagarde:}

I would like to express my gratitude to the International Monetary Fund (IMF) for its continued support of our economic reforms. Tajikistan has emerged from the global crisis, but nonetheless remains vulnerable to external shocks. Continued support from international financial institutions (IFIs) and donors will be critical in safely navigating these risks.

Economic performance in 2010 was strong, and has continued in the first half of 2011. Despite adverse weather conditions and the negative impact of high food and fuel prices, real GDP growth registered 6.9 percent during the first six months of 2011, fueled by trade and services, agriculture, and construction. However, inflation has been high, reflecting trends in international food and fuel markets. Financial sector indicators also remain a concern, and we continue to devote attention to finding a solution for this problem.

There have also been significant challenges to macroeconomic management. As explained in the attached Memorandum of Economic and Financial policies, external shocks, and liquidity needs by the banking system led to deviations from program targets for net international reserves of the National Bank of Tajikistan (NBT), and the level of liquidity support to commercial banks. Pension arrears also briefly emerged in September and October 2011 due to an unanticipated shortfall in wage taxes (which cover pension payments). These arrears were cleared as of October 20 and November 30, 2011, respectively.

In response to these slippages, and to bring performance back on track with program objectives, monetary and fiscal policies have been tightened in the second half of 2011. This should, inter alia, help to ease pressures on inflation and the balance of payments, ensure compliance with revised program targets, and prepare Tajikistan for any potential regional or global economic slowdown. The central bank policy rate was raised by 100 basis points as of mid-October, and the terms on NBT liquidity loans have also been tightened considerably. The NBT will also maintain the outstanding stock of liquidity loans at an average outstanding 
balance of SM 100 million by end-December - in line with the revised path agreed with IMF staff. On the fiscal side, we are committed to keeping the fiscal deficit (excluding the externally financed public investment program) to no more than 0.6 percent of GDP, but will also save any over-performance in excess of this goal to help rebuild the fiscal buffers drawn down during recent years.

On the structural side, all but one of the benchmarks for the first half of 2011 were completed. The coverage of the Large Taxpayer Inspectorate was increased, banks not meeting prudential standards submitted action plans, a government resolution on recapitalization of the NBT was passed, Roghun OJSC released its fifth quarterly financial report in September, and audited financial statements for Talco Management were published in November. I am also pleased to inform you that the first shareholder meeting of Roghun OJSC was conducted in May 2011. We have also recently published the audited 2010 financial statements of the NBT, in accordance with a structural benchmark for endSeptember. However, due to delays in inter-ministerial approval and a survey of fixed assets, it was not possible to complete the audit of Roghun OJSC in line with the timing set out in the program. We ask that this benchmark be rephased to March 2012.

We are committed to achieving the reforms outlined in the Memorandum of Economic and Financial Policies (MEFP) of November 9, 2010. However, while recent economic performance is encouraging, we remain concerned about inflation, the risk of another global downturn, and the potential impact on Tajikistan in terms of growth, poverty, and fiscal and external balances. We ask the international community for assistance in these areas. We also recognize the potential macroeconomic and financial ramifications of the Roghun project. We remain committed to ensuring that this project and its financing are undertaken in a way consistent with macroeconomic stability, and external and fiscal sustainability.

We hereby request completion by the Executive Board of the fifth review under the ECF arrangement, and disbursement of the sixth loan totaling an amount equivalent to SDR 13.045 million. In parallel, we seek continued concessional support from donors for the coming year to achieve the objectives of the 2010-12 Poverty Reduction Strategy. For the fifth review under the ECF arrangement we request waivers for nonobservance of the performance criteria on NIR of the NBT on the basis of the corrective actions outlined in the MEFP, and for the continuous performance criterion on pension arrears on the basis that these arrears were small and corrected within a short period. We also request modification of the quantitative performance criteria on NDA, NIR, and the fiscal deficit for end-December 2011, as well as indicative targets, and structural benchmarks described in the attached tables, the MEFP of December 22, 2011, and Technical Memorandum of Understanding (TMU) to enable us to monitor progress in implementing our reform agenda.

The Government believes that the policies set forth in this letter and the MEFP are adequate to achieve the objectives of its program, but will take any further measures that may become 
appropriate for this purpose. We will consult with the Fund on the adoption of these measures and in advance of any revision to the policies contained in the MEFP, in accordance with the Fund's policies on such consultation. We intend to remain in close consultation with Fund staff and provide timely information necessary for monitoring economic developments and implementation of policies under the ECF arrangement. In addition, the Government stands ready to take any further measures that might be required to ensure that the overall objectives of the program are attained.

Finally, in continuing with our commitment to transparency, we hereby request that all program related documents, including this letter, be published on the IMF website.

Your Excellency, please accept my assurances of my highest consideration,

$$
\text { /s/ }
$$

Emomali Rakhmon

President of the Republic of Tajikistan 
Table 1. Tajikistan: Quantitative Performance Criteria and Indicative Targets under the 2011 Extended Credit Facility (In millions of somoni; unless otherwise indicated)

\begin{tabular}{|c|c|c|c|c|c|c|c|c|c|}
\hline & & \multirow{3}{*}{$\begin{array}{c}2010 \\
\text { End-Dec } \\
\text { Act. }\end{array}$} & \multirow{2}{*}{\multicolumn{4}{|c|}{$\frac{2011}{\text { End-Sept. }}$}} & \multirow{3}{*}{$\begin{array}{l}\text { End-Dec. } \\
\text { Rev. Prog. }\end{array}$} & \multicolumn{2}{|c|}{2012} \\
\hline & & & & & & & & \multirow{2}{*}{$\begin{array}{c}\text { End-Mar } \\
\text { Prog. } \\
\end{array}$} & \multirow{2}{*}{$\begin{array}{c}\text { End-Dec. } \\
\text { Proj. }\end{array}$} \\
\hline & & & Prog. & Act. & Prog. & Act. & & & \\
\hline & Quantitative Performance Criteria (PC): & & & & & & & & \\
\hline 1. & Ceiling on cumulative flow of net domestic assets of the NBT $1 / 2 /$ & $\ldots$ & 120 & 19 & 210 & 213 & 678 & -112 & 398 \\
\hline 2. & Floor on cumulative flow of total net international reserves (in millions of U.S. dollars) $1 / 2 /$ & $\ldots$ & 25 & 3 & 45 & 21 & 32 & 12 & 49 \\
\hline 3. & $\begin{array}{l}\text { Zero-ceiling on new lending from the NBT to private sector (continuous quantitative performance } \\
\text { criterion) } 2 /\end{array}$ & $\ldots$ & 0 & 0 & 0 & 0 & 0 & 0 & 0 \\
\hline 4. & $\begin{array}{l}\text { Floor on cumulative overall fiscal balance of the general government excluding foreign-financed } \\
\text { Public Investment Program and related grants } 2 /\end{array}$ & $\ldots$ & -134 & 150 & -208 & 301 & -187 & 207 & -180 \\
\hline 5. & $\begin{array}{l}\text { Ceiling on general government wage and pension arrears (continuous quantitative performance } \\
\text { criterion) }\end{array}$ & $\ldots$ & 0 & 0 & 0 & 4 & 4 & 0 & 0 \\
\hline 6. & $\begin{array}{l}\text { Ceiling on contracting or guaranteeing of any non-concessional external debt (continuous quantitative } \\
\text { performance criterion) }\end{array}$ & $\ldots$ & 0 & 0 & 0 & 0 & 0 & 0 & 0 \\
\hline 7. & Ceiling on disbursements of concessional external financing (in millions of U.S. dollars) $2 /$ & $\ldots$ & 154 & 87 & 231 & 142 & 308 & 71 & 285 \\
\hline \multirow[t]{2}{*}{8.} & New external payments arrears (continuous quantitative performance criterion) & $\ldots$ & 0 & 0 & 0 & 0 & 0 & 0 & 0 \\
\hline & Indicative Targets (IT): & & & & & & & & \\
\hline 1. & Floor on tax collection $2 /$ & $\ldots$ & 2,470 & 2,717 & 3,837 & 4,211 & 5,759 & 1,563 & 6,998 \\
\hline 2. & Floor on social and poverty-related expenditure $2 /$ & $\ldots$ & 1,421 & 1,200 & 2,131 & 1,853 & 2,841 & 881 & 3,524 \\
\hline 3. & Ceiling on gross equity sales and contributions for Roghun (in millions of somoni) $3 /$ & $\ldots$ & 880 & 840 & 880 & 841 & 880 & 880 & 880 \\
\hline \multirow[t]{5}{*}{4.} & Ceiling on loans to banks for liquidity purposes by the NBT (average per quarter) & $\ldots$ & 227 & 263 & 244 & 218 & 100 & 100 & 100 \\
\hline & Memorandum items: & & & & & & & & \\
\hline & Program exchange rate & 4.40 & & & & & & & \\
\hline & NDA of the NBT (in millions of somoni) $1 /$ & 1,739 & 1,285 & 1,758 & 1,375 & 1,952 & 2,417 & 2,305 & 2,815 \\
\hline & Net international reserves (in millions of U.S. dollars) $1 / 4 /$ & 376 & 400 & 378 & 420 & 397 & 408 & 419 & 457 \\
\hline
\end{tabular}

2/ Cumulative from January 1 of the year; performance criteria for end-June and end-December 2011, and indicative targets for end-March and end-September.

3/ Cumulative from January 1, 2010.

4/ Adjusted for presumed forward sale of foreign exchange on June 30, 2011 in the amount of 10.8 million U.S. dollars. 
Table 2. Tajikistan: Structural Benchmarks and Prior Actions for 2011 and 2012

Date

Rationale

Status

Publish the audited financial statements of Talco Management for 2008-09 together with the audit reports.

NBT to set the interest rate on liquidity loans in Somoni and foreign exchange no lower than the average interest rate on commercial bank credits (as published on the NBT website) of the preceding month, plus a margin of not less than 200 basis points, and to publish this rate on the NBT website.

Appoint a senior member of the ministry of finance to attend monthly monetary policy committee meetings and to report on monthly projected spending on the Roghun hydropower

project.

Banks not meeting established prudential criteria to submit to NBT for approval time-bound actions plans to become fully compliant with these standards, including correct provisioning for nonperforming loans.

Expand the number of large taxpayers under the Large Taxpayer Inspectorate (LTI).

Issue a government resolution specifying a multi-year (2011-18) schedule for injections of capital from the government into the NBT as part of the NBT recapitalization plan and in line with IMF recommendations.

NBT Board to approve an action plan, in line with IMF recommendations, for addressing weaknesses in the financial sector.

National Bank of Tajikistan to publish audited 2010 financial statement

Submit to cabinet a strategy for reform of the tax regime.

Fiscal risk statement related to condition of SOEs to be introduced as part of the published 2012 budget document.

Publish the audited financial statements of Roghun OJSC for 2008 and 2009 with the audit reports on the Ministry of Finance's website.

Submit to cabinet a revised tax code consistent with IMF recommendations.

Implement in line with IMF recommendations a Treasury Single Account (TSA) at the Republican level.
Prior action for

Transparency

Board meeting

Prior action for

Transparency

Board meeting

Prior action for

Board meeting

Transparency/liquidity management

End-March

Financial sector stability

End-June

End-June

NBT recapitalization

End-June

Financial sector stability

End-

September

End-

September

End-December

SOE governance

End-March

2012

End-March

2012

April 1, 2012
Met on June 24, 2011

Met on Nov. 17, 2011

Met

Met

Met on

March 31, 2011

Met

Met on June 30, 2011

Met on Dec. 13, 2011

Met
Transparency

Revenue/transparency

Public financial management 


\section{Attachment II. Tajikistan: Memorandum of Economic and Financial Policies (MEFP) FOR 2011-12}

\section{December 22, 2011}

\section{INTRODUCTION}

1. This memorandum outlines economic and financial policies of the Government of Tajikistan for 2011-12, and augments the letter of intent and the memorandum of economic and financial policies dated November 9, 2010 focusing on our policies for the remainder of 2011 and 2012. These policies are intended to serve as the basis for the ongoing IMF-supported program under the Extended Credit Facility (ECF).

2. Tajikistan has emerged from the global economic downturn of 2009, but continues to navigate through an uncertain economic environment. Real economic growth rose to 6.5 percent in 2010, and to 6.9 percent through the first half of 2011 - driven by domestic trade and services, as well as agriculture, construction, and industry. We expect real GDP growth to reach at least 6 percent for the year as a whole. The post-crisis recovery of inward remittances has been an essential pillar in supporting the recovery, and reflects both the rebound in neighboring economies and Tajikistan's close ties to the region. Total inward remittances increased by about 40 percent year-on-year through June, providing welcome income support. However, inflation has been high for most of the year-reflecting the surge in international food and fuel prices, as well as the imposition of higher taxes on imported fuel products. We expect end-2011 inflation to be about 13 percent or less, falling further in 2012 as commodity prices decline. Financial sector indicators remain a concern but have stabilized in recent months.

3. Macroeconomic management in the first half of 2011 was challenging. Despite heavy external shocks related to import of fuel products, we increased international reserves, remained current on all financial obligations, exceeded targets for tax collection, and kept the government budget in line with program targets. However, four quantitative targets under our program for June were missed - the performance criteria on net international reserves (NIR) of the National Bank of Tajikistan (NBT); the continuous performance criterion on nonaccumulation of wage and pension arrears; and indicative targets on government social spending and on liquidity loans from the NBT). Fuel price shocks and the need to smooth short-term volatility in the somoni contributed to lower NIR accumulation. The shortfall in government social spending is linked to the timing of government wage and salary increases and the continued high level of vacancies in health and education. Pension arrears emerged in September and October, due to a shortfall in tax receipts on salaries. These arrears have already been cleared.

4. In this environment, our program focuses on fostering the recovery and providing greater support to the poor, while taking actions to address the pressures that emerged in the 
first half of 2011 and thus ensure macroeconomic, fiscal, and balance of payments sustainability. We have reached understandings with IMF staff on a set of prior actions for the fifth review, and on quantitative performance criteria, indicative targets, and structural benchmarks for the remainder of 2011 and 2012. Key pillars include closer coordination of fiscal and monetary policies, infrastructure projects to address Tajikistan's energy bottlenecks, accelerating structural reforms in support of private sector-led growth, strengthening governance of public sector institutions, increasing budgetary allocations for social spending, and ensuring the safety and soundness of the financial sector.

5. Our macroeconomic policies are based on the government's National Development Strategy for the period until 2015, and the 2010-12 Poverty Reduction Strategy (PRS). In the short term, our program aims to maintain macroeconomic stability - which is a precondition for sustained high growth and poverty reduction. Structural reforms in the financial and state-owned enterprise (SOE) sectors are designed to enhance the potential for higher and more inclusive economic growth over the medium term. We intend to move forward with infrastructure projects in the energy sector, which we see as essential to sustained growth and, in turn, poverty reduction. In this context, we are committed to the principle that planned increases in better-targeted social spending and associated recurrent costs be fully covered by revenue from tax, administrative, and public financial management reforms. Given limited fiscal space, we are working closely with the Development Coordination Council to further streamline and prioritize the PRS, fulfilling commitments under the Action Plan agreed in the December 2010 development forum.

\section{MACroeconomic Policies For 2011-12}

6. Within our overall macroeconomic policy framework, the construction of the Roghun hydropower plant (HPP) is of the highest strategic importance to address Tajikistan's energy deficit and thus lay the foundation for future growth and poverty reduction. This will be crucial to meet Tajikistan's growing energy needs, though additional generation capacity and significant maintenance on existing facilities is also likely to be needed. The Roghun project has significant ramifications for macroeconomic policies, and will continue to have an impact on fiscal and balance of payments performance in 2011 and beyond. We are committed to ensuring the project is constructed in a way that is consistent with macroeconomic stability and fiscal and external sustainability. Techno-economic and environmental assessments are underway. Based on evaluation results we are ready to revisit our financing strategy in close consultation with IMF staff. In the meantime, it will be critical to ensure that spending on the Roghun project is carefully planned and monitored, and ensure consistency with macroeconomic objectives and program targets.

7. We have reached an understanding with IMF staff on macroeconomic policies for the remainder of 2011 and for 2012. For 2011, we expect real GDP growth to reach at least 6 percent, and year-end inflation to be about 13 percent or less. To address recent high money growth and mitigate potential pressure on inflation and on the balance of payments, the 
government has tightened fiscal and monetary policies in the second half of 2011. This has involved a reduction in NBT liquidity loans to commercial banks, and more stringent terms for such loans. No further drawdown of Roghun-related funds (raised during the 2010 financing campaign and deposited in the NBT) will be made for the remainder of 2011. NBT bills will be issued to mop-up remaining excess liquidity and keep reserve money growth in line with inflation objectives.

8. On the fiscal side, the government will fully execute the official budget agreed with IMF staff, but will seek to achieve an overall deficit of 0.6 percent of GDP on the basis of higher-than-anticipated revenues. We further commit that any additional over-performance on the budget target (either by higher revenues or lower expenditures) will be saved to rebuild the fiscal cushion drawn down during the crisis years. External borrowing will continue to be limited to a level consistent with medium-term debt sustainability and will only be undertaken on concessional terms.

9. For 2012, we expect growth to continue in the range of 6 percent, and inflation to decline to an average of about 10 percent. The government will begin a gradual process of fiscal consolidation, as envisioned in our Medium Term Expenditure Framework (MTEF) with the objective of eventually rebuilding the fiscal buffers drawn down during the 2008-09 global crisis. In line with our ongoing commitment to improve social services, the official budget will also reflect a continued rebalancing from capital expenditures to social spending (health, education, and social protection). Monetary and fiscal policies will be coordinated to ensure achievement of inflation objectives. This will include careful planning and coordination on extra-budgetary spending on Roghun, and careful use of resources raised during the sale of public shares in 2010. The NBT will also target further increases to the cushion of international reserves, and in this context will limit its interventions in the foreign exchange market to smoothing short-term excess volatility.

10. In the medium term, we hope that a more favorable international environment will pave the way toward higher growth, lower inflation, and a stronger external balance. In these circumstances we hope to significantly strengthen our international reserves position, and target reserves coverage of two months of imports by 2016. In the fiscal area, we will balance the pressing social and infrastructure spending needs, while broadly aiming for overall fiscal balance (excluding PIP), with a view to keeping government debt below the ceiling of 40 percent of GDP that we have set in our debt strategy. In this context, we are committed to strengthen public debt management and reporting by public enterprises. Our debt strategy — which we intend to revise in the near future - also addresses the fiscal impact of the cotton debt resolution. 


\section{STRUCTURAL REFORMS FOR 2011-12}

\section{A. Monetary and Financial Sector Reforms}

11. A safeguards assessment update of the NBT was completed in mid-2010. The findings indicated that initial steps have been taken to address the risks identified by the special audit on cotton sector financing, but that considerable safeguards risks - related to fragmented accounting and organizational structure, and lack of external independent oversight - remained at the NBT. An action plan (based on the main recommendations of the special audit of the NBT, as well as recommendations of the safeguards assessment) to address these deficiencies and restore the credibility of the national bank has largely been implemented (Table 1). A task force, chaired by a non-executive Board Director, to assess progress on these reforms on a semi-annual basis was appointed in June 2010. To ensure transparency and accountability, we have also completed six semi-annual external reviews of the NBT's net international reserves. One more such review is planned for December 2011. The NBT's audited financial statements for 2010 were also published on the NBT website in mid-December (structural benchmark).

12. Strengthening of the laws and regulations surrounding central bank operations has been a key pillar of reform. A revised Law on the National Bank of Tajikistan and a new Law on Resolution of Bankrupt Credit Institutions were submitted to parliament at end-2010 in line with commitments under the IMF program, and were ratified in the first half of 2011. The government also remains committed to recapitalization of the national bank. Our NBT recapitalization strategy balances the NBT's needs (strong balance sheet, instruments for monetary policy) and the government's interests (minimize fiscal costs). A first injection of government funds to the NBT equivalent to SDR 60 million received as part of the Multilateral Debt Relief Initiative has been implemented. An additional injection, through a placement of government bonds, will also be made before the end of 2011. A schedule of further injections of government capital was adopted as a government resolution in June 2011, and will be integrated into forthcoming government budgets. Efforts will also be strengthened to collect principal and interest on amounts due from cotton investors, as specified in the Presidential Order of August 2010.

13. In its monetary policy operations, the NBT will, in line with the new Law on the National Bank of Tajikistan, focus primarily on price stability. In this context, the NBT will continue to refrain from issuing new credits to the private sector, except for emergency liquidity purposes or in cases of bank distress or failure (lender of last resort). All lending to commercial banks and nonbank financial institutions is restricted to the NBT's short-term liquidity facility. To protect the NBT's balance sheet and foster a more robust interbank market, we also have moved to tighten the terms surrounding liquidity loans (reflecting their nature as emergency financing) by bringing liquidity loan interest rates to a level above prevailing bank lending rates (a structural benchmark), and (in compliance with the new 
NBT Law) will restrict such loans to solvent lending institutions with sufficient collateral but no other source of funding). To ensure these goals are met, the government will refrain from directed lending.

14. Coordination on liquidity management has been enhanced through appointment of a senior MOF official as an observer to the NBT's monetary policy committee. We will also circulate between the NBT and the MOF, and to IMF staff, a schedule of expenditure commitments (including projected import content) for the Roghun hydropower project for the last quarter of 2011 and for 2012, such that the spending on this project can be assessed against macroeconomic and program objectives.

15. Building a sound financial system that enjoys public trust and contributes to private sector-led growth is a priority. Based on recommendations from the World Bank and IMF, the NBT also adopted in June 2011 a Financial Sector Stability Action Plan (Table 2) which comprises a series of reforms through March 2012 to bolster the transparency of bank operations and accounting, and contribute to financial system stability. Progress in implementing this plan is being monitored in coordination with the IMF. To further support this effort and build public confidence in the banking system, we are, in consultation with the World Bank, seeking assistance from the FIRST Initiative to support technical assistance to strengthen bank regulation (including licensing procedures, asset classification, provisioning, risk management, and internal controls), strengthen supervision of banks and deposit-taking microfinance organizations, move toward consolidated and risk-based supervision, and develop prompt remedial action frameworks. The government has also issued a decree to raise the interest rate, beginning January 2012, on bonds placed with banks as part of the cotton debt resolution, with a view to strengthening banks' balance sheets. Subject to the availability of fiscal resources, we will consider further improvements in the terms of these bonds in 2012.

\section{B. Fiscal Reforms}

16. A fair, efficient, and transparent tax system is an essential element in creating a robust business environment. Over the years and through successive amendments, Tajikistan's tax code has become difficult to understand and implement, and in some areas has strayed from best principles for tax policy. To address these problems, broaden the tax base, and foster private sector-led economic growth, we are committed to redrafting the tax code in line with IMF recommendations by early 2012 (structural benchmark) with a view to implementing the revised code in 2013. We ask the international community for continued support and technical assistance in this area.

17. Improvements in tax administration will also help to raise government revenue over the medium term and foster a transparent business environment. With the support of the Asian Development Bank, we have embarked on a three-year development plan aimed at improving the efficiency of the tax authorities and strengthening public-private dialogue 
between tax authorities and taxpayers. The coverage of the Large Taxpayer Inspectorate (LTI) has been increased in 2011 (structural benchmark) and will be increased further in 2012. In line with IMF recommendation, the operations of the Tax Authority will also be restructured along functional lines with a view to boosting the efficiency of tax collection efforts.

18. We are also pursuing steps to further enhance public financial and debt management. In this context, our public financial management strategy aims at the introduction of a full Treasury Single Account (TSA) system at the Republican level by April 2012 (benchmark), together with implementation of an electronic financial management information system to support the TSA. We are committed to prudent debt management, and will restrict our external borrowing to loans on concessional terms. To avoid potential problems vis-à-vis the requirements under the program, we have strengthened coordination with IMF staff to ensure that an appropriate level of concessionality is achieved for all new loans. We undertook a Debt Management Performance Assessment (DEMPA) by the World Bank in April 2011, followed by a reform plan exercise in July 2011. We agree with the findings of the DEMPA report. We intend to publish the results of the report and aim to implement recommended reforms to improve debt management capacity. Donor support to finance a comprehensive reform plan would be helpful. Further, we have strengthened the monitoring framework for government guaranteed debts through enhanced notification procedures prior to payment dates with both borrowers and lenders. Finally, with donor-supported technical assistance, a fiscal risk assessment covering the condition of Tajikistan's state owned enterprises (SOEs) will be prepared in the context of the 2012 budget (structural benchmark).

\section{State Owned Enterprises, Agriculture, and Data}

\section{State-Owned Enterprises}

19. We are taking steps to address financial weaknesses - including inter-enterprise and tax arrears - in key SOEs and put them on sound financial footing. Some arrears reflect structural deficits in SOEs, while others reflect nonpayment of dues from government entities. Tax arrears represent foregone government revenue, while inter-enterprise arrears pose a potential fiscal liability and a threat to macroeconomic stability. We seek a lasting and financially viable means of addressing these problems, and to subject SOEs to financial discipline going forward. For the near-term, we have ensured that the 2011 and 2012 budgets include sufficient resources for all spending agencies to remain current on their obligations.

20. The SOE Supervisory Unit has made substantial progress in its operations, with the help of the European Union and IMF technical assistance. The unit has assessed the financial performance of SOEs for 2010, and their 2011 financial plans. The unit has also prepared and published reports on SOE performance that will be published on the ministry of finance's website on a semi-annual basis. By June 2011, all SOE's subject to review by the SOE unit (MOF) have been required to publish on the MOF website 2010 financial statements and 
results of external audits conducted in line with accepted standards of auditing. We will be looking to the international community for further technical assistance to support these important efforts to boost transparency and public financial accountability.

21. Tajikistan Aluminum Company (Talco) has undergone an external audit of its 2006-09 financial statements, and the audit report and the financial statements together with the audit opinions have been published on the company's website. Audited financial statements for 2010, along with the audit opinion, were posted on the company's website in November. Supported by the World Bank, an audit of TALCO's energy use will also be undertaken in 2011 to identify options for increasing efficiency. Talco Management has also completed an external audit of its financial statements and published the results on the company website.

\section{State electricity company Barki Tajik will—with World Bank and Asian}

Development Bank support - undertake a reform program through 2013 that will include, among other measures, restructuring into functional units, a resolution of arrears, and adjustments in electricity tariffs with a view to progressively achieve cost recovery.

\section{Agriculture}

23. We remain committed to market-oriented and private sector-led comprehensive agriculture reforms, leading to long-term growth and development of agricultural production, and improvement of the rural populations' lives and livelihoods. Agriculture is a key pillar of the national economy. Agricultural growth and development will entail production means intensification, diversification of the sector through sustainable use and management of natural resources, and establishment of market-based vehicles for sustainable agricultural financing. In this context, the government will, by end-2011, approve the Action Plan of the Agrarian Reform agreed with donors and where necessary advocate parliamentary approval. With support from development partners, we will prepare sector development strategies for agriculture, water, and land for the period 2012-20.

\section{Data}

24. We plan to continue to improving our national accounts and price statistics, with technical assistance from the regional IMF statistics advisor, who will coordinate closely with the STATCAP project led by the World Bank. With IMF assistance, we will also continue to improve the quality and timeliness of our monetary and balance of payments statistics, which are essential to the conduct of sound macroeconomic policies.

25. Strengthening our debt data management framework is a priority. We have completed an inventory of government domestic debt and domestic and external debt of SOEs. This information has been published, together with a report on government and governmentguaranteed external debt, in the 2011 budget documents. In addition, the NBT continues to 
strengthen the monitoring system of private external debt, and began publishing these data on the NBT website on a semi-annual basis starting as of June 2010 - sharing this data on a quarterly basis with the ministry of finance.

\section{Program Monitoring}

26. We will continue to monitor progress in implementing the program through quantitative performance criteria and indicative targets, as well as prior actions, and structural benchmarks set for 2011 and 2012. These are listed in the tables attached to the letter of intent. The technical memorandum of understanding which is also attached to this letter defines the quantitative targets of the program and their adjustors, and specifies reporting requirements. Completion of the sixth review under the ECF arrangement-which is envisaged for April 18, 2012 - will require observance of the quantitative performance criteria for end-December 2011 and other relevant performance criteria. 
Table 1: NBT Reform Action Plan

\begin{tabular}{|c|c|c|}
\hline Reform & Timing & Status \\
\hline \multicolumn{3}{|l|}{ GOVERNANCE } \\
\hline Close down the Cotton Debt Department at the NBT. & June 2009 & Done \\
\hline $\begin{array}{l}\text { Develop proposals to restructure the NBT' organizational } \\
\text { set up }\end{array}$ & $\begin{array}{l}\text { December } \\
2010\end{array}$ & \\
\hline $\begin{array}{l}\text { Appoint the NBT Board for a fixed term with } 3 \\
\text { non-executive members. }\end{array}$ & June 2010 & Done \\
\hline $\begin{array}{l}\text { Establish NBT Board Committees, such as an audit } \\
\text { committee, chaired by a non-executive member of the NBT } \\
\text { Board. }\end{array}$ & June 2010 & Done \\
\hline $\begin{array}{l}\text { Create and publish on the NBT's website a register of } \\
\text { commercial interests of NBT Board members and top } \\
\text { management }\end{array}$ & June 2010 & Done \\
\hline $\begin{array}{l}\text { A draft revised central bank law substantially compliant } \\
\text { with the recommendations of Fund staff should be } \\
\text { approved by the President of the Republic and submitted to } \\
\text { Parliament for enactment. }\end{array}$ & $\begin{array}{l}\text { December } \\
2010\end{array}$ & Done \\
\hline \multicolumn{3}{|l|}{ AUDITING } \\
\hline $\begin{array}{l}\text { The appointment of the external auditor for the } 8 \text { months } \\
\text { ended December } 31,2009 \text { should be finalized in time for } \\
\text { the external auditor to attend vault counts in headquarters } \\
\text { and all branches to confirm the balances in vaults as well } \\
\text { as unissued currency at end-December. }\end{array}$ & $\begin{array}{l}\text { Before end- } \\
\text { December } \\
2009\end{array}$ & Done. \\
\hline $\begin{array}{l}\text { External audit of the April } 2009 \text { financial accounts to be } \\
\text { completed. }\end{array}$ & $\begin{array}{l}\text { Prior action } \\
\text { for } 1^{\text {st }} \text { and } 2^{\text {nd }} \\
\text { reviews }\end{array}$ & $\begin{array}{l}\text { Done. Audit posted } \\
\text { on NBT website in } \\
\text { April } 2010 .\end{array}$ \\
\hline $\begin{array}{l}\text { Continue NIR reviews by an international audit firm at test } \\
\text { dates under the ECF arrangement. Such reviews should be } \\
\text { completed before the IMF Board meeting and the TOR for } \\
\text { the reviews should be adapted as needed to ensure that (i) } \\
\text { the auditor attends vault counts on the relevant test date; } \\
\text { (ii) emerging issues are addressed; and (iii) previous }\end{array}$ & $\begin{array}{l}\text { End-June } \\
2011 \text { audit } \\
\text { prior to fifth } \\
\text { Board } \\
\text { meeting. }\end{array}$ & Done \\
\hline
\end{tabular}




\begin{tabular}{|c|c|c|}
\hline Reform & Timing & Status \\
\hline \multicolumn{3}{|l|}{ recommendations are being addressed. } \\
\hline $\begin{array}{l}\text { Publish on its external website in a dedicated section the } \\
\text { financial statements and audit opinion within } 1 \text { month from } \\
\text { completion of the audit, also including all past audit reports. }\end{array}$ & Continuous & $\begin{array}{l}\text { Completed for } \\
\text { fiscal year ending } \\
\text { April 2009, } \\
\text { December 2009, } \\
\text { and } 2010 \text {. }\end{array}$ \\
\hline $\begin{array}{l}\text { Develop an internal regulation to define a formal policy for } \\
\text { the selection and appointment of its external auditor. The } \\
\text { policy should stipulate: (i) the composition of the selection } \\
\text { committee, including participation by non-executive Board } \\
\text { members; (ii) criteria for making the selection; (iii) a timeline } \\
\text { for the tendering, bidding and appointment, ensuring the } \\
\text { contracting of the external audit not later than } 3 \text { months } \\
\text { before the year-end; and (iv) multi-year audit contracts. }\end{array}$ & $\begin{array}{l}\text { By September } \\
2010 \text {, in time } \\
\text { for the } 2010 \\
\text { audit selection }\end{array}$ & Done \\
\hline $\begin{array}{l}\text { Outsource-through a formal tendering process-to an } \\
\text { external consulting firm the internal audit of the activities of } \\
\text { (i) the international relations department, including foreign } \\
\text { exchange lending and liquidity support; (ii) the domestic } \\
\text { lending and liquidity support activities; and (iii) the } \\
\text { management of foreign currency vault operations at } \\
\text { headquarters. Ensure that external consultant contributes } \\
\text { to capacity building in the Internal Audit Department. }\end{array}$ & April 2010 & Done \\
\hline $\begin{array}{l}\text { Plan and organize an external quality assurance review of } \\
\text { the NBT's Internal Audit Department by certified experts on } \\
\text { its compliance with Institute of Internal Auditors (IIA) } \\
\text { standards. }\end{array}$ & June 2011 & $\begin{array}{l}\text { Extended for } 5 \\
\text { years in line with } \\
\text { IMF TA } \\
\text { recommendations }\end{array}$ \\
\hline \multicolumn{3}{|l|}{ ACCOUNTING AND OPERATIONS } \\
\hline $\begin{array}{l}\text { Create a new base of the NBT balance sheets and } \\
\text { continuously monitor their conformity with analytical data }\end{array}$ & June 2009 & Done \\
\hline $\begin{array}{l}\text { Keep full records of adjustments made with regard to } \\
\text { audited financial reports, and keep full records to confirm } \\
\text { the data that the IMF publishes in its reports }\end{array}$ & Continuously & $\begin{array}{l}\text { Completed for } \\
2009 .\end{array}$ \\
\hline $\begin{array}{l}\text { Increase the number of sudden checks of cash available in } \\
\text { the NBT's head office and regional branches. }\end{array}$ & Continuously & Done \\
\hline Develop a mechanism to transfer and share information & Continuously & Done \\
\hline
\end{tabular}




\begin{tabular}{|l|l|l|}
\hline \multicolumn{1}{|c|}{ Reform } & Timing & Status \\
\hline $\begin{array}{l}\text { between departments on any reclassification of items in the } \\
\text { NBT's accounting balance sheet for the purpose of } \\
\text { compiling the monetary analysis. }\end{array}$ & & \\
\hline $\begin{array}{l}\text { Establish a register of the gold bars held in the NBT vaults, } \\
\text { including gold owned by the ministry of finance. This } \\
\text { register must include details on the serial number of the } \\
\text { gold bars and the ownership. This register must be } \\
\text { included in the scope of the NIR review, starting with the } \\
\text { end-December 2009 test date. }\end{array}$ & March 2010 & Done \\
\hline $\begin{array}{l}\text { Take measures to create a centralized accounting system } \\
\text { of the NBT by transferring all accounting functions to } \\
\text { relevant departments and introduce software for centralized } \\
\text { recording of transactions done by the NBT's regional } \\
\text { branches. }\end{array}$ & June 2010 & $\begin{array}{l}\text { All departments } \\
\text { excluding } \\
\text { International } \\
\text { Reserves } \\
\text { Department now } \\
\text { part of centralized } \\
\text { accounting system. }\end{array}$ \\
\hline $\begin{array}{l}\text { Include the issue of accounting and monitoring of the NBT } \\
\text { balance sheet items in daily meetings of the working group. } \\
\text { Include representatives of the internal audit and accounting } \\
\text { into the working group } \\
\text { the front-office, back-office and accounting functions in } \\
\text { order to mitigate operational risks. }\end{array}$ & & $\begin{array}{l}\text { Not done. No } \\
\text { representation from } \\
\text { Audit Department }\end{array}$ \\
\hline
\end{tabular}


Table 2: Financial Sector Stability Action Plan

\begin{tabular}{|l|l|l|}
\hline Reform & Timing & Status \\
\hline $\begin{array}{l}\text { Asset Quality } \\
\begin{array}{l}\text { NBT to approve regulation on uniform } \\
\text { classification and provisioning } \\
\text { (Regulation 177). }\end{array}\end{array}$ & July 2011 & Done \\
\hline $\begin{array}{l}\text { Banks to fully provision for NPLs in } \\
\text { accordance with established prudential } \\
\text { criteria. }\end{array}$ & August 2011 & Done \\
\hline $\begin{array}{l}\text { All banks to work on an accrual basis } \\
\text { and (i) stop accruing interest on NPLs, } \\
\text { or (ii) make 100 percent provision for } \\
\text { interest earned on NPLs. }\end{array}$ & August 2011 & Done \\
\hline $\begin{array}{l}\text { Banks to provide for treasury bills } \\
\text { issued in lieu of cotton sector NPLs, in } \\
\text { accordance with international financial } \\
\text { reporting standards (IFRS) principles. }\end{array}$ & September 2011 & Done \\
\hline $\begin{array}{l}\text { Banks to implement regulation 177 to } \\
\text { ensure uniform classification of NPLs } \\
\text { and full provisioning. }\end{array}$ & September 2011 & Done \\
\hline $\begin{array}{l}\text { In accordance with Regulation 177, } \\
\text { banks to upgrade NPLs to a category } \\
\text { requiring lower provisioning only after } \\
\text { all amounts due (including principal } \\
\text { and interest) have been repaid and the } \\
\text { borrower continues to service the loan } \\
\text { without default at least for 6 months. } \\
\text { rescheduled accounts to remain in the } \\
\text { same asset classification as at the time } \\
\text { of the restructuring (for the first } \\
\text { restructuring) and downgrade by at }\end{array}$ & September 2011 & Done \\
\hline
\end{tabular}




\begin{tabular}{|c|c|c|}
\hline $\begin{array}{l}\text { least one level for the second } \\
\text { restructuring. }\end{array}$ & & \\
\hline $\begin{array}{l}\text { In accordance with regulation } 177, \\
\text { NBT to allow banks to upgrade } \\
\text { rescheduled NPLs to standard category } \\
\text { only after they demonstrate satisfactory } \\
\text { performance under the revised terms } \\
\text { for at least } 6 \text { months. }\end{array}$ & September 2011 & Done \\
\hline \multicolumn{3}{|l|}{$\begin{array}{l}\text { Liquidity, Funding, and Contingency } \\
\text { Planning }\end{array}$} \\
\hline $\begin{array}{l}\text { NBT to require banks to reflect all } \\
\text { material corrections from the annual } \\
\text { external audits in their general ledgers } \\
\text { to make retroactive corrections. }\end{array}$ & July 2011 & Done \\
\hline $\begin{array}{l}\text { NBT to prepare, on a rolling basis, } \\
\text { contingency plans to meet and } \\
\text { overcome vulnerabilities in individual } \\
\text { banks that may arise during the } \\
\text { following } 12 \text { months. }\end{array}$ & August 2011 & Done \\
\hline $\begin{array}{l}\text { To assess liquidity position of banks, } \\
\text { NBT to require an independent audit } \\
\text { for cash counts in all banks. }\end{array}$ & September 2011 & $\begin{array}{l}\text { Partially completed. } \\
\text { Several banks allowed to } \\
\text { finalize audits by end- } \\
2011 \text {. }\end{array}$ \\
\hline $\begin{array}{l}\text { Banks most vulnerable to liquidity and } \\
\text { funding risks to submit contingency } \\
\text { liquidity and funding plans for } \\
\text { managing liquidity under stressful } \\
\text { situations and rectify structural } \\
\text { liquidity and funding imbalances, } \\
\text { without any reliance on NBT's liquidity } \\
\text { facilities. }\end{array}$ & October 2011 & Done \\
\hline \multicolumn{3}{|l|}{ Provisioning and Capitalization } \\
\hline $\begin{array}{l}\text { In line with regulation } 177 \text {, banks to } \\
\text { provision for re-possessed assets, on } \\
\text { par with those of doubtful assets. }\end{array}$ & November 2011 & Not completed \\
\hline
\end{tabular}




\begin{tabular}{|l|l|l|}
\hline $\begin{array}{l}\text { Banks to maintain higher level of } \\
\text { provisions and capital for exposures to } \\
\text { customers who have unhedged foreign } \\
\text { currency risk exposures; and comply } \\
\text { with proposed prudential limits for such } \\
\text { exposures. }\end{array}$ & November 2011 & Not completed \\
\hline $\begin{array}{l}\text { Increase the minimum capital-to-asset } \\
\text { ratio (CAR) for the top 6 banks from 12 } \\
\text { to 15 percent. }\end{array}$ & December 2011 & \\
\hline $\begin{array}{l}\text { NBT to adjust banks' capital adequacy } \\
\text { position for correct provisions and asset } \\
\text { valuation until actual implementation } \\
\text { by banks, and require those banks that } \\
\text { either breach or are close to breaching } \\
\text { the regulatory minimum to infuse } \\
\text { capital within a prescribed timeframe. }\end{array}$ & December 2011 & \\
\hline $\begin{array}{l}\text { NBT to improve its prompt remedial } \\
\text { action framework (PRAF) including } \\
\text { reviewing and understanding the } \\
\text { shortcomings of the current framework, } \\
\text { creating a supervisory manual covering } \\
\text { off- and on-site aspects, develop } \\
\text { internal guidelines, procedures, and } \\
\text { sanctions to ensure effective remedies } \\
\text { are initiated at the earliest stage of bank } \\
\text { problems. }\end{array}$ & & \\
\hline $\begin{array}{l}\text { NBT to review its supervisory function } \\
\text { and undertake an assessment of its } \\
\text { compliance with the gaps identified by } \\
\text { the assessment of Basel Core Principles } \\
\text { (BCP) for effective banking } \\
\text { supervision conducted in February } \\
\text { 2011. }\end{array}$ & March 2012 & \\
\hline
\end{tabular}




\section{AtTachment III. Tajikistan: Addendum to Technical Memorandum of UNDERSTANDING}

This addendum supplements the Technical Memorandum of Understanding (TMU) of April 19, 2011. It updates the definitions and adjusters of these targets. Unless an update is provided in this TMU, the definitions, adjusters and reporting requirements outlined in the TMU of April 19, 2011 apply to the program targets set for end-December 2011 and end-March 2012.

Quantitative Performance Criterion 1: Ceiling on a cumulative flow of net domestic assets of the NBT for the year.

Adjustor for budgetary grants. The cumulative NDA flow is adjusted upward (downward) for the negative (positive) difference between actual and programmed budgetary grants recorded in revenue.

Quantitative Performance Criterion 2: Floor on a cumulative flow for the year of total net international reserves (in millions of U.S. dollars).

Adjustor for budgetary grants. The cumulative NIR flow will be adjusted downward (upward) for the negative (positive) difference between actual and programmed budgetary grants recorded in revenue.

Quantitative Performance Criterion 4: Floor on the cumulative overall fiscal balance of the general government excluding foreign-financed PIP and related grants.

Adjustor for budgetary grants. The floor on the cumulative overall fiscal balance of the general government excluding foreign-financed PIP and related grants will be adjusted downward, i.e., the deficit target will be increased, (upward, i.e., the deficit target will be reduced) by the amount of the negative (positive) difference between actual and programmed budgetary grants recorded in revenue. 
INTERNATIONAL MONETARY FUND

REPUBLIC OF TAJIKISTAN

Fifth Review Under the Three-Year Arrangement Under the Extended Credit Facility, Request for Waiver of Nonobservance of Performance Criteria, and Request for Modification of Performance Criteria-Informational Annex

Prepared by the Middle East and Central Asia Department in Consultation with Other Departments

Approved by David Owen and Dhaneshwar Ghura

December 22, 2011

Contents

I. Relations with the Fund $\underline{2}$

II. Relations with the World Bank Group....................................................................... 


\section{RELATIONS WITH THE FUND}

(As of October 31, 2011)

I. Membership Status: Joined April 27, 1993; Article VIII

II. General Resources Account:

$\underline{\text { SDR million }}$

\% Quota

87.00

100.00

Quota

87.00

100.00

Fund holdings of currency

0.00

0.00

Reserve position in Fund

III. SDR Department

Net cumulative allocation

$\underline{\text { SDR million }}$

\% Allocation

Holdings

82.08

100

69.78

85.01

IV. Outstanding Purchases and Loans

$\underline{\text { SDR million }}$

\% Quota

78.31

90.01

ECF Arrangements

V. Latest Financial Arrangements

\begin{tabular}{llccr} 
Type & $\begin{array}{c}\text { Approval } \\
\text { Date }\end{array}$ & $\begin{array}{c}\text { Expiration } \\
\text { Date }\end{array}$ & $\begin{array}{c}\text { Amount Approved } \\
\text { (SDR million) }\end{array}$ & $\begin{array}{c}\text { Amount Drawn } \\
\text { (SDR million) }\end{array}$ \\
\hline ECF $^{12}$ & Apr 21, 2009 & Apr 20, 2012 & 104.40 & 78.31 \\
ECF & Dec 11, 2002 & Feb 10, 2006 & 65.00 & 65.00 \\
ECF & Jun 24, 1998 & Dec 24, 2001 & 100.30 & 78.28
\end{tabular}

VI. Projected Payments to Fund ${ }^{13}$

\begin{tabular}{lccccc}
\hline & \multicolumn{5}{c}{ Forthcoming } \\
\cline { 2 - 6 } & 2011 & 2012 & 2013 & 2014 & 2015 \\
\hline Principal & & & & 2.61 & 7.83 \\
Charges/Interest & 0.01 & 0.24 & 0.24 & 0.23 & 0.22 \\
$\quad$ Total & 0.01 & 0.24 & 0.24 & 2.84 & 8.06
\end{tabular}

\footnotetext{
${ }^{12}$ Formerly PRGF.

${ }^{13}$ When a member has overdue financial obligations outstanding for more than three months, the amount of such arrears will be shown in this section.
} 


\section{Implementation of HIPC Initiative:}

\section{Not Applicable}

\section{Implementation of Multilateral Debt Relief Initiative (MDRI):}
I. MDRI-eligible debt (SDR Million) ${ }^{14}$
69.31
Financed by: MDRI Trust
69.31
Remaining HIPC resources

II. Debt Relief by Facility (SDR Million)

\begin{tabular}{llll}
\multicolumn{4}{c}{ Eligible Debt } \\
\hline Delivery Date & $\underline{\text { GRA }}$ & $\underline{\text { PRGT }}$ & $\underline{\text { Total }}$ \\
January 2006 & N/A & 69.31 & 69.31
\end{tabular}

\section{Safeguards Assessment}

The 2009 update assessment of the NBT noted considerable safeguard risks in key functions such as accounting, NIR compilation, the control environment, and the NBT's organizational structure. Independent governance mechanisms were largely absent, in particular for overseeing audit mechanisms, and the internal audit function was weak. Subsequently, an NBT reform action plan was drawn up, and since 2009 several measures have been implemented, including six-monthly reviews of NIR data by an external auditor. One more such review is planned for December 2011.

Audited financial statements are published on the NBT website, albeit with some delays. These delays, combined with limited capacity in the accounting area, can raise the risk of inadvertent misreporting. The internal audit of core functions was recently outsourced, while the NBT is strengthening its internal audit capacity through on-the-job training and technical assistance.

A recent safeguards staff visit concluded that increased transparency and oversight of key operations, notably large scale support of local banks, is needed to help safeguard IMF resources.

\footnotetext{
${ }^{14}$ The MDRI provides 100 percent debt relief to eligible member countries that qualified for the assistance. Grant assistance from the MDRI Trust and HIPC resources provide debt relief to cover the full stock of debt owed to the Fund as of end-2004 that remains outstanding at the time the member qualifies for such debt relief.
} 


\section{Exchange Rate Arrangements}

Since March 2011, the de facto exchange rate regime is classified as craw-like. The official exchange rate is based on all interbank transactions in foreign exchange. It is calculated and announced daily.

With effect from December 9, 2004, the Republic of Tajikistan accepted the obligations of Article VIII, Sections 2, 3, and 4 of the Articles of Agreement. The Republic of Tajikistan maintains an exchange system that is free of restrictions on the making of payments and transfers for current international transactions, except for exchange restrictions maintained for security reasons that have been notified to the Fund pursuant to Executive Board decision No. $144-(52 / 51)$.

\section{FSAP Participation}

Tajikistan participated in the Financial Sector Assessment Program during 2007-08, and the FSSA report has been published at http://www.imf.org/external/country/TJK/index.htm.

\section{Article IV Consultation}

The 2011 Article IV consultation was completed on May 11, 2011.

\section{Resident Representative}

Mr. Aisen, Resident Representative of the Fund, started his assignment in Dushanbe in July 2010.

\section{Technical Assistance}

The following list summarizes the technical assistance provided by the Fund to Tajikistan since 2004.

\section{Fiscal Affairs:}

July 2004

December 2004

June 2005

August 2005

August 2006

May 2007
Revenue Administration Reform

Poverty and Social Impact Analysis

Public Financial Management

Tax Policy and Administration

Fiscal ROSC

Public Financial Management (Budget Classification) 
February/July 2010

June 2010

November 2010

February/March2011
Tax Policy and Administration

Public Financial Management Reforms

Public Financial Management (Regional Advisor)

New Tax Code

Monetary and Financial Systems:

May 2006

Strengthening the Monetary Policy Framework and Liquidity Management

October/December 2009 and September 2010

January 2011

October 2011

Statistics:

April 2004

October 2004

June 2006

March 2011

September 2011
NBT Recapitalization Strategy

Improving Accounting Controls at NBT Foreign Reserves Management, Internal Audit, Accounting and Recapitalization

\section{Data ROSC}

General Data Dissemination System (GDDS)

Report on Monetary and Financial Statistics

National accounts and price statistics (Regional Advisor)

BOP

Safeguards Monitoring

Tax Legislation

Tax Legislation

AML/CFT

NBT Law

Tax Policy/ Tax Code 


\section{ANNEX II. TAJIKISTAN: RELATIONS WITH THE WORLD BANK GROUP}

(As of September 30, 2011)

27. The Fund's mission met with the World Bank's team during the IMF's September 2011 mission in Dushanbe and in Washington to identify macro critical structural reforms and coordinate the two teams' work for the period September 2011-September 2012. Subsequent interaction in Dushanbe and Washington with staff of both institutions led to finalization of this memorandum.

28. Tajikistan's economy continues to recover from the global economic crisis, but remains vulnerable to exogenous shocks. Despite lower than anticipated rainfall in the early part of 2011, growth appears relatively strong. Inflation has remained a key concern, however, particularly given the negative impact on the poor. The teams agreed that, apart from the need to maintain strong growth and achieve lasting poverty reduction, Tajikistan's main macroeconomic challenges are: (i) to meet - within the context of fiscal and debt sustainability - the country's pressing spending needs while maintaining public debt at or below the authorities' 40 percent of GDP ceiling; (ii) to further strengthen central bank governance and enhance the effectiveness of monetary policy; (iii) to subject the state enterprise sector to greater transparency and financial discipline; and (iv) to develop the financial sector, strengthen bank supervision, and provide for an effective intermediation of savings and investment.

29. Based on this shared assessment, the teams identified six structural reform areas as macro critical, and agreed on the division of labor in these areas:

- Central bank governance and operations: Due to past directed credits, the central bank has large negative capital. Despite recent governance improvements, checks and balances need to be strengthened further, and the central bank needs to be recapitalized, eliminating crucial constraints to the effectiveness of monetary policy. Key reform areas include: monetary policy formulation, central bank independence and role as lender of last resort, internal and external audit processes, budgeting, and monetary instruments. The Fund takes the lead.

- Agricultural sector reform: The sector employs 70 percent of the population (mainly low income households), but suffers from excessive government intervention that holds back its growth potential. Key reform areas include: agriculture financing, land reform and property rights, building infrastructure for non-cotton agriculture products. The Bank and other donors take the lead.

- Energy sector reform: The sector fails to provide reliable electricity supply to the country, while running large deficits that are financed through underinvestment in capital and maintenance, as well as tax and inter-enterprise arrears. Key reform areas include: increasing production capacity, improving transmission and distribution 
infrastructure, improved planning of winter energy management and export of summer surplus power, conducting energy audits of key state enterprises, and rationalizing the tariff structure to achieve cost recovery. A reform priority is to strengthen the power utilities' financial controls and reporting system. The Bank takes the lead.

Investment Climate Reform: Tajikistan's corporate sector is held back by a business environment that is not conducive to private sector investment and growth. Key reform areas include: reducing risk and uncertainty for the entrepreneur, removing barriers to entry, reducing the cost of doing business, and supporting the private sector to increase productivity and human capacity to drive growth. The Bank leads, on the basis of its latest survey-based investment climate assessment. The tax system also features prominently, and the Fund will take the lead on tax policy, in cooperation with any sector-specific work (such as agricultural taxation) undertaken by donors, while the Bank will take the lead on tax administration, in cooperation with the Fund and other donors.

- $\quad$ Public financial management reform: Despite recent reforms, budgeting and financing procedures can still be significantly improved, with potentially large benefits for fiscal policy. Key reform areas include: implementation of the Treasury Single Account, closer monitoring of fiscal aspects of large state-owned enterprises (SOEs), social services and safety net reform. The Fund's FAD regional TA advisor works on budget classification issues and SOE monitoring, aiming to reduce quasifiscal activities and increase transparency. The Bank leads the switch to per capita based financing in education and health sectors, and will also continue to support public financial external and internal control reform. It will also work on a social spending strategy, and thus assist the implementation of the Fund's ECF benchmark on increasing social spending.

- $\quad$ Financial sector reform: Tajikistan's financial sector is underdeveloped. Only a small amount of savings is channeled through the banking system, and private sector credit extension is insufficient to facilitate strong, sustained, private-sector-led economic growth. Key reform areas include interbank market, strengthening regulations and supervision, deposit insurance law, and securities market. A Financial Sector Assessment Program (the country's first), carried out jointly by the Bank and the Fund, was discussed with the authorities in late 2007. The Bank leads on supporting implementation of the assessment's recommendations, working on commercial banking laws, the deposit insurance law, AML/CFT issues, and an overall financial sector strategy (in cooperation with the Fund). The Fund leads on Central Bank reform, securities market development, and certain aspects of financial sector supervision (in cooperation with the Bank).

30. The teams have the following requests for information from their counterparts: 
- $\quad$ The Fund team requests to be kept informed of progress in the above macro critical structural reform areas. Timing: when milestones are reached (and at least semiannually).

- $\quad$ The Bank team requests to be kept informed of the Fund's assessments of macroeconomic policies and prospects. Timing: in the context of Art. IV and other missions (and at least semi-annually)

31. The appendix lists the teams' separate and joint work programs during September 2011-August 2012. 
Table 1: JMAP Implementation, September 2011-September 2012

\begin{tabular}{|c|c|c|c|}
\hline Title & $\begin{array}{c}\text { Products and brief description } \\
\text { (pillars) }\end{array}$ & $\begin{array}{c}\text { Provisional } \\
\text { Timing of } \\
\text { Missions } \\
\end{array}$ & $\begin{array}{c}\text { Expected } \\
\text { date of } \\
\text { Delivery } \\
\end{array}$ \\
\hline \multicolumn{4}{|c|}{ A. Mutual information on relevant work programs } \\
\hline \multirow[t]{6}{*}{$\begin{array}{l}\text { Bank Work Program in } \\
\text { next } 12 \text { months }\end{array}$} & $\begin{array}{l}\text { PDPG 6 } \\
\text { - Protecting delivery of basic services } \\
\text { within a sustainable fiscal framework } \\
\text { - Improving the environment for private } \\
\text { sector development and growth } \\
\text { - Strengthening government } \\
\text { effectiveness }\end{array}$ & $\begin{array}{l}\text { Identification/Pre- } \\
\text { appraisal } \\
\text { December } 2011 \\
\text { Appraisal June } \\
2012\end{array}$ & $\begin{array}{l}\text { Board August } \\
2012 \\
\text { Disbursement: } \\
\text { October } 2012\end{array}$ \\
\hline & Private Sector Development Dialogue & $\begin{array}{l}\text { PSD TA support } \\
\text { (Doing Business) } \\
\text { Fall 2011, Spring } \\
2012\end{array}$ & \\
\hline & $\begin{array}{l}\text { Rural Investment Climate Study (with } \\
\text { DFID TF) }\end{array}$ & $\begin{array}{l}\text { Preliminary } \\
\text { findings of study } \\
\text { expected by } \\
\text { March } 2012\end{array}$ & \\
\hline & $\begin{array}{l}\text { Agriculture } \\
\text { TBD }\end{array}$ & & \\
\hline & $\begin{array}{l}\text { Energy_emergency operation to provide } \\
\text { electricity during the cold period from } \\
\text { alternative (commercial) sources } \\
\text { Conducting assessment studies for the } \\
\text { Roghun HPP project }\end{array}$ & $\begin{array}{l}\text { Supervision of } \\
\text { Energy Loss } \\
\text { Reduction Project } \\
\text { (with additional } \\
\text { financing for } \\
\text { emergency } \\
\text { operation) } \\
\text { Sept. , 2011 } \\
\text { Contract award-- } \\
\text { Oct. } 2010 \text { and } \\
\text { December } 2010\end{array}$ & \\
\hline & Social safety nets & $\begin{array}{l}\text { Social assistance } \\
\text { reforms; } \\
\text { analytical work on } \\
\text { impact of energy } \\
\text { tariff increases on } \\
\text { the poor. } \\
\text { Implementation } \\
\text { mission } \\
\text { - November } 2011\end{array}$ & May 2011 \\
\hline
\end{tabular}




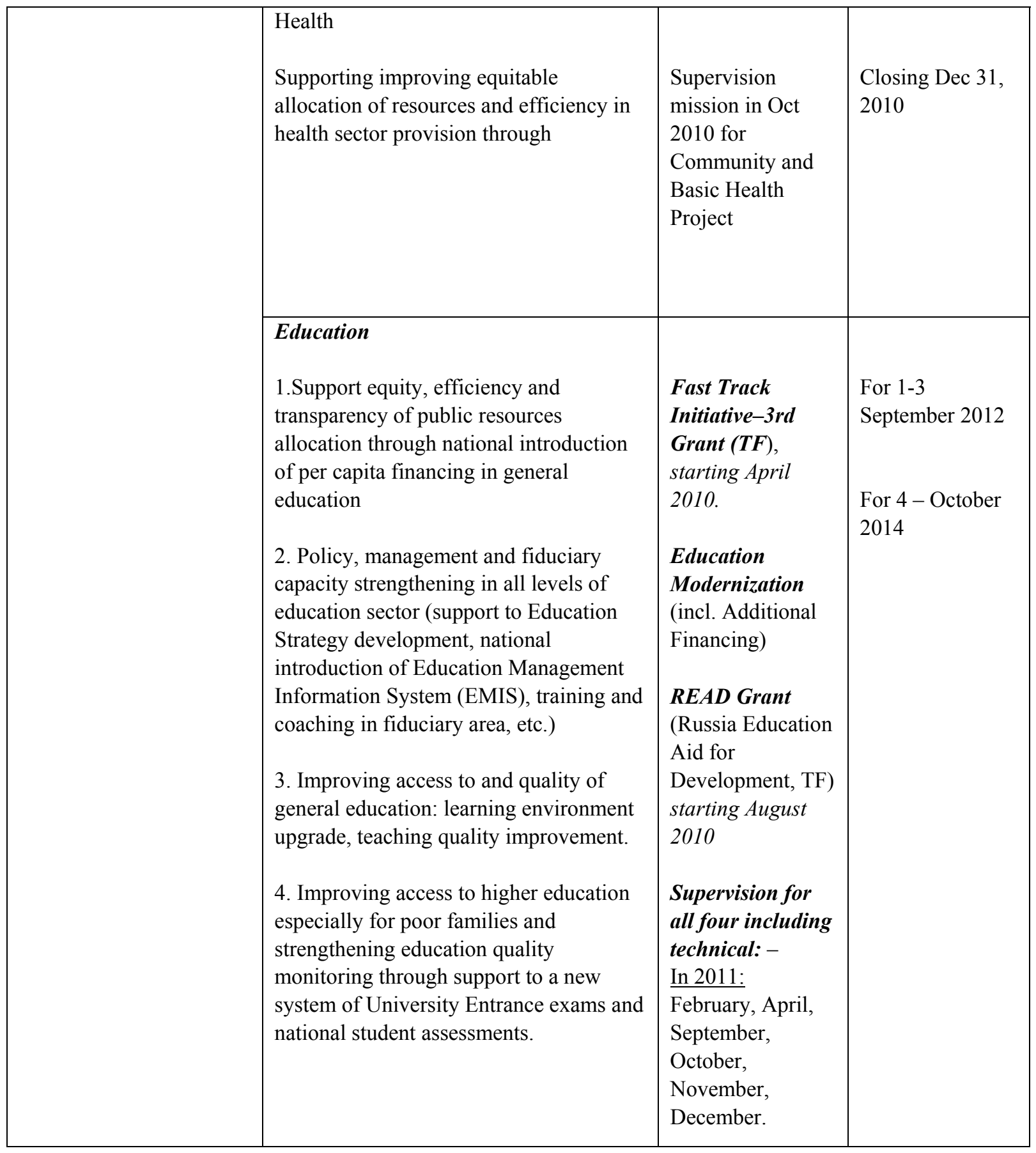




\begin{tabular}{|c|c|c|c|}
\hline & $\begin{array}{l}\text { Financial Sector } \\
\text { Fall 2011: WB FSD mission on secured } \\
\text { transactions, National Processing Center } \\
\text { for card payments } \\
\text { Jan-Feb 2012: WB \& FIRST TA mission } \\
\text { on bank regulation and supervision, } \\
\text { secured transactions, insurance law and } \\
\text { regulations } \\
\text { April-May 2012: WB \& FIRST TA } \\
\text { mission on bank regulation and } \\
\text { supervision, secured transactions, } \\
\text { insurance law and regulations } \\
\text { Aug-Sept 2012: WB \& FIRST TA } \\
\text { mission on bank regulation and } \\
\text { supervision, secured transactions, } \\
\text { insurance law and regulations }\end{array}$ & & \\
\hline $\begin{array}{l}\text { Fund work program in } \\
\text { next } 12 \text { months }\end{array}$ & $\begin{array}{l}\text { - Fifth ECF review staff report } \\
\text { - TA report on NBT accounting / internal } \\
\text { audit/foreign reserves management } \\
\text { - NBT safeguards monitoring visit } \\
\text { - TA mission on drafting of new tax } \\
\text { code } \\
\text { - Sixth ECF review }\end{array}$ & $\begin{array}{l}\text { September 2011: } \\
\text { Fifth ECF review } \\
\text { mission } \\
\text { October } 2011 \\
\text { mission (MCM) } \\
\text { September } 2011 \\
\text { October 2011 } \\
\text { February/March } \\
\text { 2012: Sixth ECF } \\
\text { review mission }\end{array}$ & $\begin{array}{l}\text { December 2011: } \\
\text { Fifth ECF review } \\
\text { board meeting } \\
\text { October } 2011 \\
\text { TA report by } \\
\text { Nov. } 2011 \\
\\
\text { April/May 2012: } \\
\text { Sixth ECF } \\
\text { review board } \\
\text { meeting }\end{array}$ \\
\hline Fund request to Bank & $\begin{array}{l}\text { - Follow-up on Barki Tajik audit } \\
\text { - Electricity tariff increases } \\
\text { - Roghun feasibility study } \\
\text { - Cotton/agriculture sector reforms } \\
\text { - Any STATCAP work on NA and } \\
\text { inflation statistics } \\
\text { - PFM work } \\
\text { - Social spending } \\
\text { - Financial sector work- }\end{array}$ & & \\
\hline
\end{tabular}




\begin{tabular}{|l|l|l|l|}
\hline Bank request to Fund & $\begin{array}{l}\text {-Provide BOP/fiscal data for updating } \\
\text { macro data base annual meetings }\end{array}$ & $\begin{array}{l}\text { October 2011 } \\
\text { March 2012 } \\
\text { Spring / Summer } \\
2012\end{array}$ & \\
& Assessment letter for PDPG6 & $\begin{array}{l}\text { December } \\
2011\end{array}$ & $\begin{array}{l}\text { December 2011 donor } \\
\text { conference }\end{array}$ \\
\hline $\begin{array}{l}\text { Joint products in next } \\
\text { 12 months }\end{array}$ & $\begin{array}{l}\text { Coordinated presentation to donor } \\
\text { conference }\end{array}$ & $\begin{array}{l}\text { TBD } \\
\text { Public Expenditure Review (Bank lead, } \\
\text { IMF input) }\end{array}$ & \\
\hline
\end{tabular}


Press Release No. 12/3

International Monetary Fund

FOR IMMEDIATE RELEASE

Washington, D.C. 20431 USA

January 9, 2012

\section{IMF Executive Board Completes Fifth Review Under ECF Arrangement for Tajikistan and Approves US\$20.1 Million Disbursement}

The Executive Board of the International Monetary Fund (IMF) has completed its fifth review of Tajikistan's economic performance under a program supported by the Extended Credit Facility (ECF) arrangement. The decision enables the authorities to draw an amount equivalent to SDR 13.045 million (US\$20.1 million), bringing total disbursements under the arrangement to an amount equivalent to SDR 91.355 million (US\$140.9 million).

The three-year SDR 104.4 million (about US\$116 million) ECF arrangement with Tajikistan was originally approved by the IMF's Executive Board on April 21, 2009 and subsequently augmented on June 7, 2010 (see Press Releases No. 09/136 and No. 10/230).

In completing the review the Executive Board approved the authorities' request for waivers of nonobservance of the performance criteria on net international reserves, and wage and pension arrears. The Board also approved the authorities' request for modification of endDecember 2011 performance criteria on net domestic assets, net international reserves, and the budget deficit, as well as the indicative targets on tax revenue and National Bank of Tajikistan liquidity loans.

Following the Executive Board discussion, Mr. Zhu, Deputy Managing Director and Acting Chair, said:

“Tajikistan's economy continues to recover. Despite adverse external shocks, implementation of sound policies under the IMF-supported program has helped ensure strong growth. Inflation also appears to be on a downward path. However, the country faces a number of challenges going forward, including potential risks from a deterioration in the global economic environment.

"Higher prices for imported fuel products have had a significant and negative effect on the balance of payments during 2011-limiting the central bank's ability to accumulate foreign 
exchange reserves. The authorities responded appropriately by tightening fiscal and monetary policies, allowing some depreciation of the somoni, and seeking alternative sources for key petroleum products. Continued flexibility in the exchange rate, along with close coordination on fiscal and monetary policies, will be essential for dealing with future shocks. In this context, and to ensure medium-term fiscal and debt sustainability, the government has committed to reduce the budget deficit in 2012 and beyond.

"Ongoing structural reforms are geared toward improving governance and transparency, the investment environment, and Tajikistan's growth potential. The tax code is being redrafted and simplified, tax administration is being improved to increase the efficiency of collection and bolster public revenues, and public financial management is being strengthened to enhance transparency and monitoring of key state enterprises.

"While key banking indicators have stabilized, ongoing efforts to strengthen accounting and provisioning rules along with supervision are critical. The authorities intend to press ahead with reforms in this area, in line with a financial sector reform plan developed by the National Bank of Tajikistan this year, while closely monitoring systemically important institutions." 


\section{Statement by Mr. Weber and Mr. Ubaidulloev on Republic of Tajikistan January 9, 2012}

1. Our Tajik authorities highly value the Fund's financial and technical assistance, which they consider to be a crucial cornerstone of their development strategy. This assistance helps them to design and implement stability- and growth-oriented macroeconomic and structural policies, which in turn provide the necessary assurances to the broader international donor community. The strong conditionality under the present Extended Credit Facility (ECF) arrangement is conducive to these objectives. Our authorities would like to thank the staff for their valuable support and the always constructive dialogue on difficult policy choices and implementation challenges. They agree with the staff's appraisal and recommendations and remain fully committed to adhere to the program. Our authorities thus ask the Board to favorably consider the completion of this fifth review under the ECF arrangement.

2. The staff report is appropriately candid, both regarding the performance under the program as well as the generally risky environment. The authorities would like to emphasize the economy's vulnerability to external shocks, some of which are triggered by others' policy actions. These shocks have-in the recent period — contributed in a major way to the volatility of macroeconomic indicators and the need to seek waivers for missing two of the eight quantitative performance criteria. These challenges notwithstanding, progress on the structural reform agenda has been strong, with three prior actions and six of the remaining seven structural benchmarks met. The authorities will steadfastly pursue this reform agenda, which attaches particular importance to subjecting public entities to high standards of accountability and transparency.

3. To bring performance back on track with program objectives, the authorities have notably tightened monetary and fiscal policies while maintaining the pace of structural reforms, in line with program commitments. They are ready to take further measures, in close consultation with staff, should they become necessary.

- On the fiscal side, the authorities agreed with the staff to fully execute the budget, but to save the higher-than-expected revenues such that the 2011 fiscal deficit would be reduced from 1 percent of GDP, as planned originally under the program, to 0.6 percent of GDP. From 2012 on, the authorities will enter a gradual fiscal consolidation path, as envisioned in the Medium-Term Expenditure Framework (MTEF), with the objective of eventually rebuilding the fiscal buffers drawn down during the crisis years. In line with the authorities' commitment to improve social services, the 2012 budget envisages an increase in social spending of 23.4 percent compared to 2011.

- The central bank policy rate was raised by 100 basis points as of mid-October, and the terms of National Bank of Tajikistan (NBT) liquidity loans have been made significantly more stringent (see fourth bullet). The NBT also maintained the outstanding stock of 
liquidity loans at an average outstanding balance of 100 million Somoni until the end of the year, in line with the revised path agreed with the staff. Looking ahead, monetary policy will continue to target reserve money as the nominal anchor with a focus on containing inflation, while allowing for sufficient exchange rate flexibility to facilitate external adjustment.

- The strengthening of the laws and regulations concerning central bank operations has been a key pillar of reform. A revised Law on the NBT and a new Law on Resolution of Bankrupt Credit Institutions were ratified by the parliament in the first half of 2011. The authorities also remain committed to the recapitalization of the NBT. A first injection of government funds to the NBT, equivalent to 60 million SDRs, received as part of the Multilateral Debt Relief Initiative, has been realized in 2010. A second capital injection amounting to 120 million Somoni was made on December 28, 2011. A multi-year schedule of further government capital injections was adopted as a government resolution in June 2011. This schedule is reflected in the government budget for 2012. The authorities will also further enhance the transparency and governance of the NBT, in accordance with the recommendations of the recent safeguards assessment.

- In its monetary operations, the NBT will focus on ensuring price stability, in line with the new NBT law. The NBT will continue to refrain from issuing new credits to the private sector, except for emergency liquidity purposes or in cases of bank distress or failure. To protect the NBT's balance sheet and foster a more robust interbank market, the terms governing NBT liquidity loans were tightened in November by (i) introducing a rulesbased mechanism which will ensure that the interest rate on these loans will always lie above the prevailing bank lending rates, and (ii) restricting such loans to solvent lending institutions with sufficient collateral. In addition, coordination on liquidity management has been enhanced through the appointment of a senior finance ministry official as an observer to the NBT's monetary policy committee.

- Public financial management is being further strengthened. To raise government revenue over the medium term and help foster a transparent business environment, the authorities are committed to redrafting the tax code in line with Fund recommendations by March 2012 , with a view to implementing the revised code in 2013. They ask the international community for continued support and technical assistance in this area. The public financial management strategy aims at introducing a full Treasury Single Account (TSA) at the republican level by April 2012, together with the implementation of an electronic financial management information system to support the TSA. Finally, the authorities are committed to restrict external borrowing to loans on concessional terms. To avoid potential problems in this regard, they have strengthened coordination with Fund staff to ensure an appropriate level of concessionality for all new loans.

- On state-owned enterprises, both the Tajikistan Aluminum Company (Talco) and its financial management company (Talco Management) have undergone external audits of 
their financial statements that have been published on the companies' websites. The external audit of the financial statements of the hydropower company Roghun OJSC has been re-phased as a structural benchmark for end-March 2012.

4. The Tajik authorities have expressed a strong interest in a continued program relationship with the Fund beyond the expiration of the current arrangement on April 20, 2012. This interest is based on their recognition of the numerous challenges emanating from Tajikistan's exposure to external shocks, the need to further build up policy making capacities, and the importance of a sound macroeconomic environment for development. 